Florida International University FIU Digital Commons

\title{
Analysis of Land Use Change as a Method of Predicting Water Demands in an Urbanizing Environment: Redland, Miami-Dade County, Florida
}

Shiva Pokharel

spokh001@fiu.edu

DOI: $10.25148 /$ etd.FI14040895

Follow this and additional works at: https://digitalcommons.fiu.edu/etd

\section{Recommended Citation}

Pokharel, Shiva, "Analysis of Land Use Change as a Method of Predicting Water Demands in an Urbanizing Environment: Redland, Miami-Dade County, Florida" (2014). FIU Electronic Theses and Dissertations. 1219.

https://digitalcommons.fiu.edu/etd/1219 


\section{FLORIDA INTERNATIONAL UNIVERSITY}

Miami, Florida

\section{ANALYSIS OF LAND USE CHANGE AS A METHOD OF PREDICTING WATER DEMANDS IN AN URBANIZING ENVIRONMENT: REDLAND, MIAMI-DADE COUNTY, FLORIDA}

A thesis submitted in partial fulfillment of the requirements for the degree of MASTER OF SCIENCE in ENVIRONMENTAL STUDIES by Shiva Prasad Pokharel 
To: Dean Kenneth Furton

College of Arts and Sciences

This thesis, written by Shiva Prasad Pokharel, and entitled Analysis of Land Use Change as a Method of Predicting Water Demands in an Urbanizing Environment: Redland, Miami-Dade County, Florida, having been approved in respect to style and intellectual content, is referred to you for judgment.

We have read this thesis and recommend that it be approved.

René M. Price

Leonard J. Scinto

Jeffrey A. Onsted, Major Professor

Date of Defense: March 27, 2014

The thesis of Shiva Prasad Pokharel is approved.

Dean Kenneth G. Furton
College of Arts and Sciences

Dean Lakshmi N. Reddi

University Graduate School

Florida International University, 2014 
(C) Copyright 2014 by Shiva Prasad Pokharel

All rights reserved. 


\section{DEDICATION}

My wife Bimala Adhikari has been my source of love, strength and inspiration. 


\section{ACKNOWLEDGMENTS}

It would not have been possible to write this thesis without the help and support of kind people around me, to only some of whom it is possible to give particular mention here.

Above all, I would like to express my sincere gratitude to my advisor Dr. Jeffrey Onsted for his continuous guidance and encouragement during the period of my thesis work. His keen supervision has enabled me to carry out the work smoothly and with high efficacy. I could not have imagined having a better advisor and mentor for my thesis. I would like to thank Dr. Rene Price and Dr. Leonard Scinto for agreeing to serve in my committee and offering insightful ideas throughout the time I was writing my thesis.

My sincere thanks also go to Department of Earth and Environment at Florida International University which awarded Teaching Assistantship that helped fund my two years of graduate study. My special thanks to Dr. Joel Heinen who provided a valuable support to my journey to FIU. I am grateful to all the professors for their wonderful classes and moral support.

I would like to thank South Florida Water Management district, Miami-Dade County Water and Sewer Department, Planning and Zoning Department for the valuable data and information.

Finally, I am thankful to my wife for her love, personal support and great patience at all times. I sincerely appreciate all my friends who have been a source of inspiration throughout my stay at FIU. 


\author{
ABSTRACT OF THE THESIS \\ ANALYSIS OF LAND USE CHANGE AS A METHOD OF PREDICTING WATER \\ DEMANDS IN AN URBANIZING ENVIRONMENT: REDLAND, MIAMI-DADE \\ COUNTY, FLORIDA \\ by
}

Shiva Prasad Pokharel

Florida International University, 2014

Professor Jeffrey A. Onsted, Major Professor

The fluctuation in water demand in the Redland community of Miami-Dade

County was examined using land use data from 2001 and 2011 and water estimation techniques provided by local and state agencies. The data was converted to $30 \mathrm{~m}$ mosaicked raster grids that indicated land use change, and associated water demand measured in gallons per day per acre. The results indicate that, first, despite an increase in population, water demand decreased overall in Redland from 2001 to 2011 . Second, conversion of agricultural lands to residential lands actually caused a decrease in water demand in most cases while acquisition of farmland by public agencies also caused a sharp decline. Third, conversion of row crops and groves to nurseries was substantial and resulted in a significant increase in water demand in all such areas converted. Finally, estimating water demand based on land use, rather than population, is a more accurate approach. 


\section{TABLE OF CONTENTS}

CHAPTER

PAGE

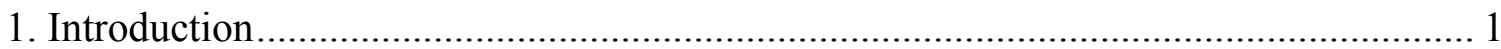

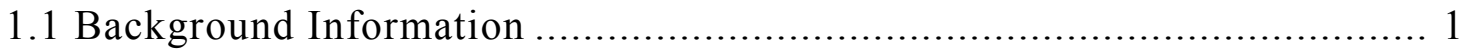

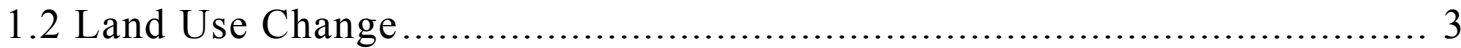

1.3 Conservation Attempts And Land Acquisition ....................................... 5

1.4 Urban Development Boundary ............................................................ 6

1.5 Population Scenarios And Water Demand …...................................... 7

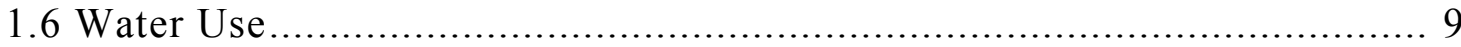

1.7 Research Questions And Hypotheses............................................... 11

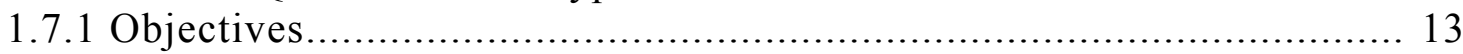

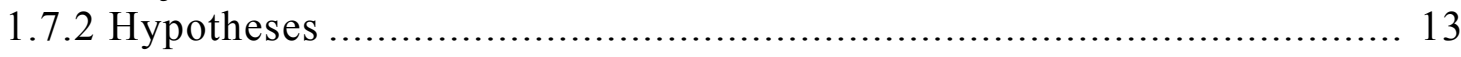

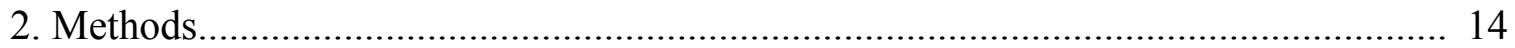

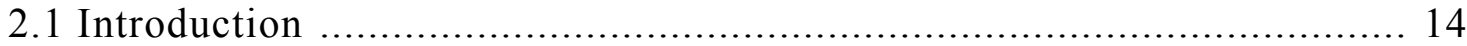

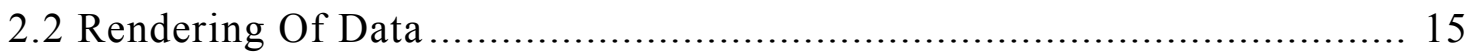

2.3 Municipal Water Estimation............................................................... 15

2.4 Estimated Water Demand For Agricultural Land Use Categories ............ 17

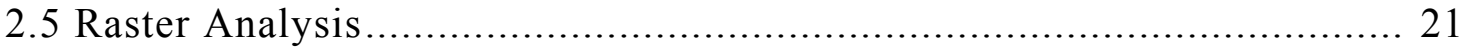

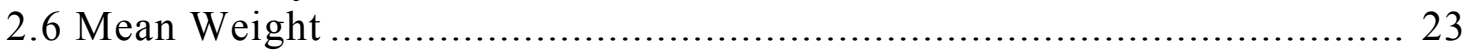

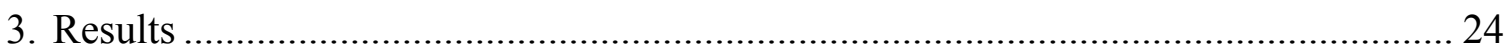

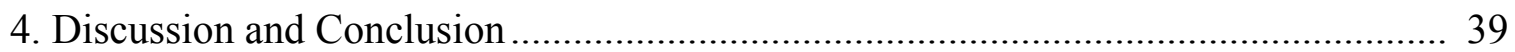

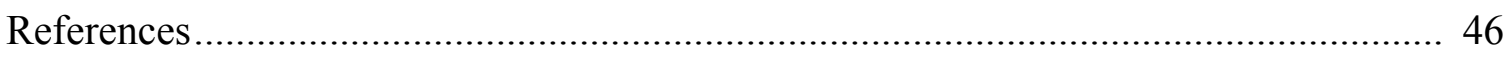

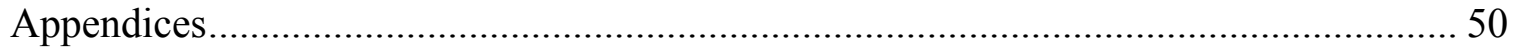

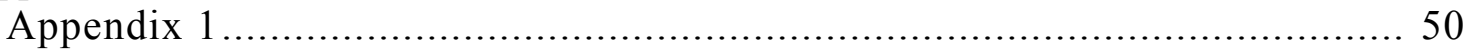

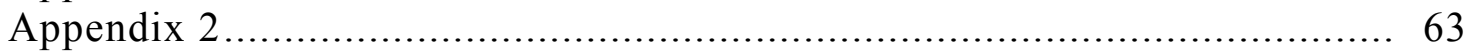

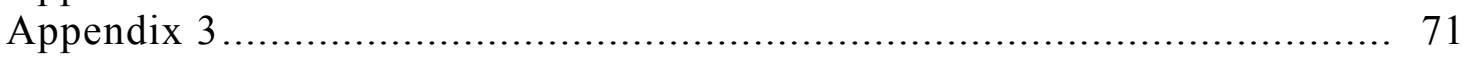

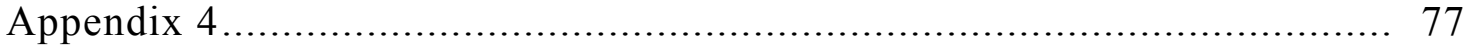




\section{LIST OF TABLES}

TABLE

PAGE

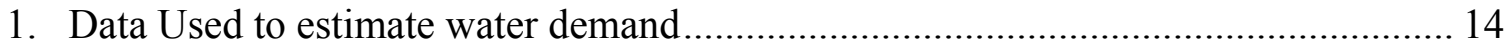

2. Translation and interpretation of Ag land classes in Appendix 4 according to SFWMD and USGS estimates of water demand per agricultural land use ............... 20

3. 2001 General Land Use in Redland ................................................................... 28

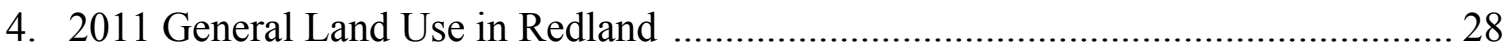

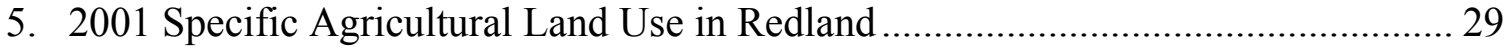

6. 2011 Specific Agricultural Land Use in Redland ............................................. 29

7. Land Changes Leading to Greatest Water Decrease in GPD. ............................... 33

8. Land Changes Leading to Greatest Water Increase in GPD. ................................. 34

9. Land Use and Water Use Change by Generalized Land Use Category..................... 38

10. Comparison of ET with allowable maximum GPD based on SFWMD permits ........ 42 


\section{LIST OF FIGURES}

FIGURE

PAGE

1. Florida located within North America and Miami-Dade County within Florida ......... 2

2. Redland located within Miami-Dade County ....................................................... 3

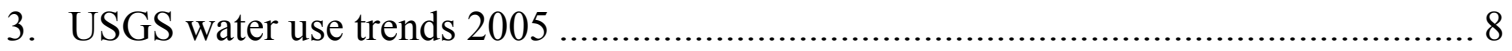

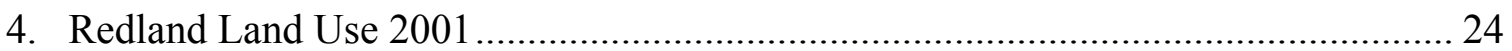

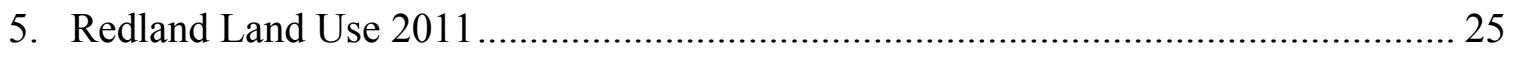

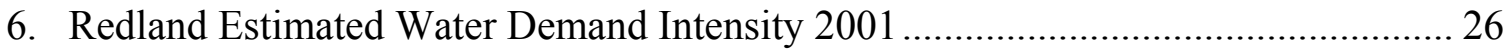

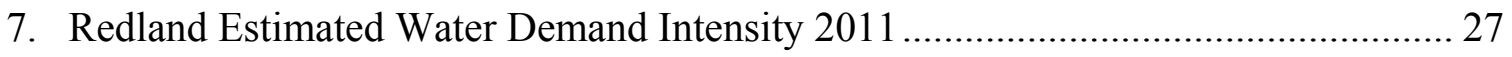

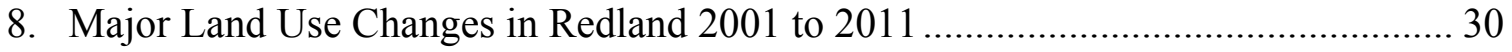

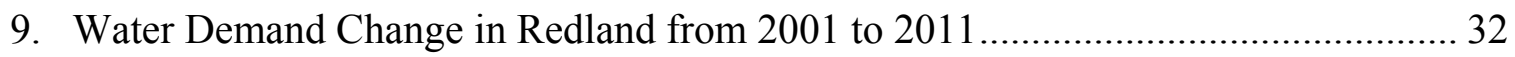

10. Land Changes associated with greatest water demand decreases in Redland ............ 33

11. Land Changes associated with greatest water demand increases in Redland ............. 34

12. Locus Shift of Water Demand in Redland from 2001 to 2011 ................................. 36 


\section{Introduction}

\subsection{Background Information}

As the human population grows, along with the per capita footprint of the average person, competition for water resources is intensifying around the world (Brian, 2002). Stakeholders include the agricultural sector as well as residential, commercial, and institutional users (such as schools, prisons, hospitals, and other government facilities). Therefore, the needs of natural habitats are often not prioritized when water management decisions are made (Viessman, 1990). South Florida offers an opportunity to identify and analyze the allocation of water resources. Although South Florida sees annual rainfall within the range of about 1000 to $1500 \mathrm{~mm}$ (McPherson and Halley, 1996), fresh water is still in high demand, especially during the dry season from November through May. Therefore, the amount of water required for urban and agricultural uses (while also leaving some available for use by natural habitats) may exceed supply, putting agriculture and domestic development in competition for the precious resource (McPherson and Halley, 1996).

Land use is often associated with different utilization rates of important environmental resources and one of those is the water (Robert, 1981). As the pace of population growth and land use change quickens along with the growing use of water intensive crops, supplying water to Miami-Dade County (MDC) will become an increasing challenge. Climate change, with its associated saltwater intrusion from sea level rise, will also impact future water resources for the area, thus exacerbating this competition (Blanco et al., 2013). 
Land use changes in MDC have reflected land use changes across the United States: loss of agricultural land to urban development (Walker et al. 1997) as well as the conversion of larger farms, typified by row and field cropland, to smaller farms, typified by nurseries (Pontius et al. under review). For instance, in 1987 MDC's average farm size was 20.5 hectares while by 2007 the average sized farm in the county dropped to 11.0 hectares (National Agricultural Statistics Service (NASS), 2012). Redland, an agricultural community in MDC situated nearly 20 miles southwest of the city of Miami Florida in the United States (Figures 1and 2), is emblematic of both of these changes and thus acts as a microcosm for MDC (in context of land use change). However, in addition to these two land use change trends, Redland has also been subject to massive public acquisition for the purposes of expanding ENP as well as for the creation of water conservation areas by the state of Florida, South Florida Water Management District (SFWMD), US Army Corps of Engineers (USACE), and MDC, thus reducing anthropogenic water demand in the area.

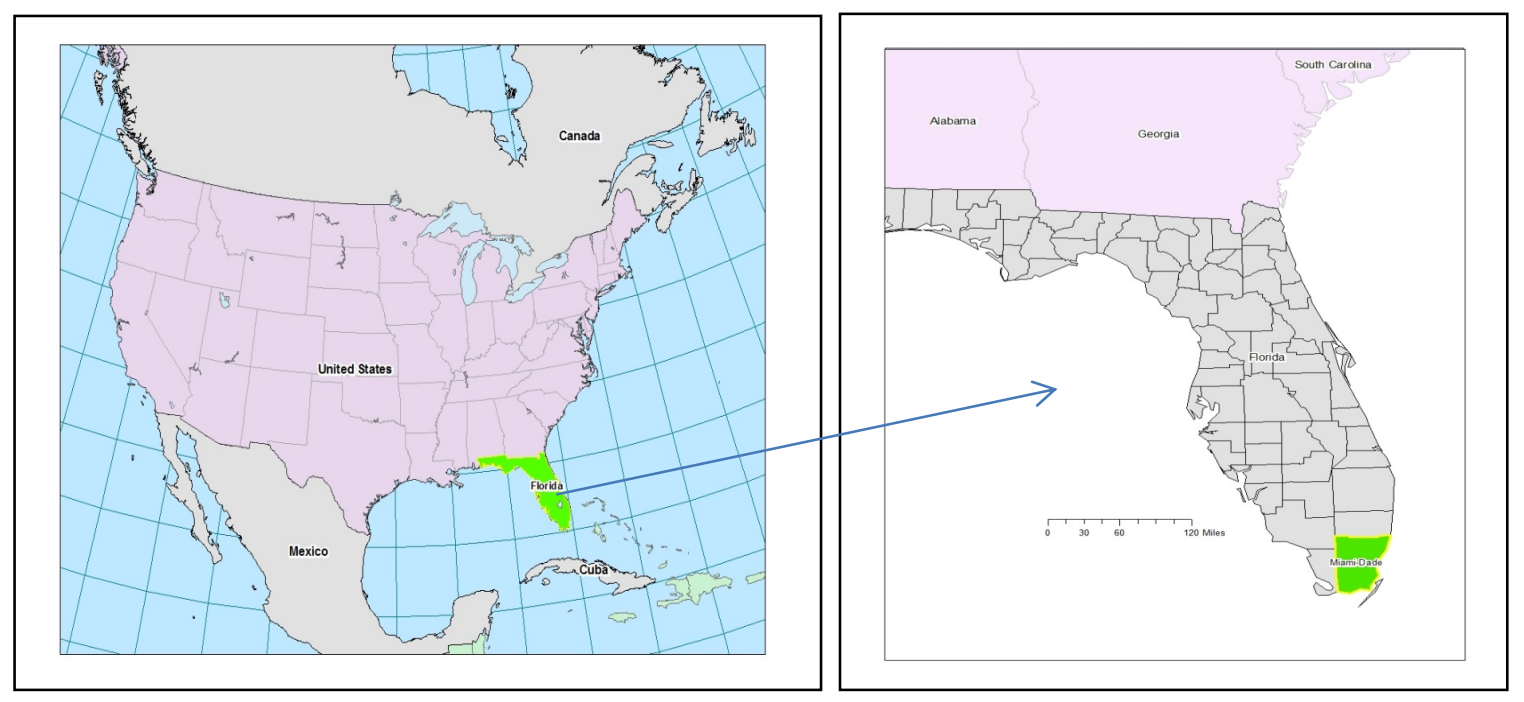

Figure 1 Florida located within North America and Miami-Dade County within Florida 


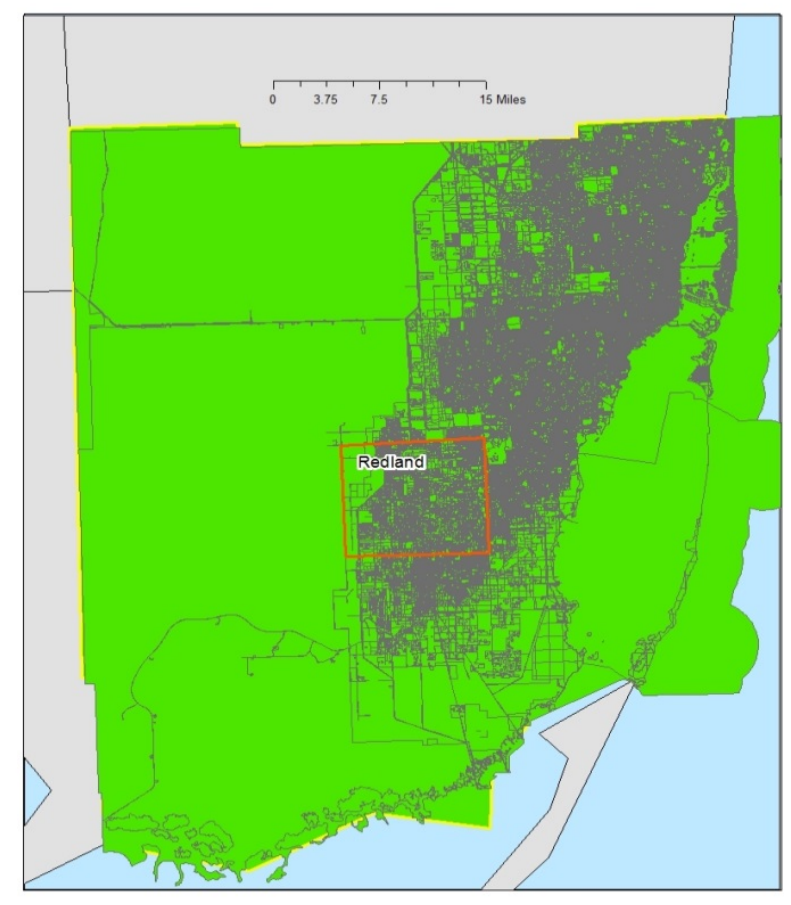

Figure 2 Redland located within Miami-Dade County

\subsection{Land Use Change}

Land use activities have transformed the vast array of land surface worldwide by both converting natural landscapes for human use and changing management practices on human dominated lands (Foley et al. 2005). So, land use change is of key importance to understanding the relationship between natural and human systems (Turner and Meyer, 1994). Land use change has been accelerated by technological changes (particularly in agriculture) and government interventions (e.g. infrastructure development) (Nerlove and Sadka, 1991).

There is urban expansion virtually in every land area in the United States in recent decades (UNEPA, 2001) and there is no exception in South Florida land use. South Florida land cover remained more or less in a natural state until the end of the 19th 
century. Though the indigenous populations were thought to be responsible for altering the landscape through hunting, foraging, and use of fire, much of the ecological integrity of the Everglades watershed remained intact until the early 1900s (Solecki, 2001). Since the early 1950s, profound modifications and conversion of land have taken place in South Florida. There were several driving forces behind this, including increased national demand for winter vegetables and fruits and rapid population growth in response to tourism and changing residential preferences, particularly among retirees (Arsenault, 1984), and of course the invention of air conditioning.

The primary goal of modification was to drain the swamp land and exploit its fertile soil along with the favorable subtropical climate for agriculture (Chimney \& Gosforth, 2001). This infrastructure development was carried out by the U.S. Army Corps of Engineers (USACE) from 1953 to 1967 as part of the federally authorized Central and Southern Florida Project for Flood Control and Other Purposes (C\&SF Project). These modifications included the construction of more than 2400 kilometers of canals and levees, 125 major water control structures, 18 major pump stations, and hundreds of smaller structures, changing the majority of the Everglade's landscape and thereby reducing the natural flow (Chimney \& Goforth, 2001). As a result, nearly half of the historical Everglades' wetlands have been reclaimed for agriculture or development (McCormick et al., 2009). The operation of this enormous and complex drainage system is controlled by the SFWMD and is considered one of the great engineering achievements in the world (Chimney \& Goforth, 2001). 


\subsection{Conservation Attempts and Land Acquisition}

People's perceptions of the Everglades have changed (Solecki et al. 1999). Observing the unintended consequences of its modification (such as loss of native species, pumping of significant amounts of valuable freshwater to sea, lowered water quality, and saltwater intrusion, etc.) has sparked a growing concern for Everglades restoration (Ibid). This led to the formulation of the largest restoration project in history called the "Comprehensive Everglades Restoration Plan" (CERP). CERP is the modified plan by the federal government to address the shortcomings of (C\&SF Project) and was approved by the U. S. Congress and signed by President Clinton in December 2000 in the Water Resources Development Act of 2000 (Perry, 2008). The USACE and SFWMD were assigned to lead the implementation of the CERP projects, this time with the aim of preservation and restoration of the Everglades. The attention of restoration efforts thus far has focused on adding water storage capacity, reducing groundwater seepage, improving regulatory delivery and timing of water to avoid environmental damage, and where feasible, improving the quality of water to be used for Everglades restoration (Perry, 2008).

For the purpose of ecological and water conservation, agriculture lands have been purchased by state and federal agencies throughout MDC in general and Redland in particular. According to Perry 2008, in Florida, there are several land acquisition programs namely Conservation and Recreation Lands (CARLS) program and Land Acquisition Trust Fund (LATF). The Federal government has also been involved in land acquisition in order to implement the Everglades Expansion and Protection Act of 1989. Also, land acquisition for water retention purposes have been highly prioritized under the 
South Florida Ecosystem Restoration Program (SFERTF Section 5) and especially the Everglades Agricultural Area (EAA) is involved in reservoir-storage development, Storm Water Treatment Areas (STA) or constructed wetlands (Aillery et al. 2001). In addition to that, some NGO's like the Audubon Society and the Nature Conservancy have also played a key role in sensitive land acquisition. More than 16,187 hectares of land have been acquired from EAA for Storm Water Management (STA) purposes (Anderson and Rosendahl, 1998). By 1991, nearly 1862 hectares of land (mostly farmland) in Redland had been acquired by ENP while SFWMD has acquired 1012 additional hectares of farmland since 1994 (MDC, 1994 and 2007).

\subsection{Urban Development Boundary}

Land use patterns in MDC have also been managed by the County's Comprehensive Development Master Plan (CDMP). The CDMP acts as a framework to identify the general parameters for land use planning and zoning, i.e. it addresses allowable land development or land conservation based on the County's policies and intentions (Miami-Dade Planning and Zoning, 2008). For this, urban and rural areas have been well demarcated by the Urban Development Boundary (UDB). The idea is to ensure that the urban activities get concentrated within the UDB and thus protect the vital natural land and productive agricultural land outside of the UDB (Groso et. al. 2005). Currently, the UDB protects the Everglades lands, MDC's groundwater well-field protection area (MDC's drinking water source) to the northwest, most of the Redland area (a prime agricultural area) to the southwest, and the Biscayne Bay watershed to the southeast. According to CDMP policy, there is a provision for amendment of the UDB; however, 
due to its agricultural importance, the Redland Agricultural Area is considered off-limits to UDB expansion (Agricultural land retention strategy).

\subsection{Population Scenarios and Water Demand}

In 1900, South Florida (defined as the seven following counties: Palm Beach, Broward, Miami-Dade, Hendry, Lee, Collier, and Monroe (not including Key West) had a very small population; only 2000 people inhabited the whole region, not including Key West (Solecki, 2001). A minimal amount of land was used for agricultural production and was only for the subsistence of locals and the consumption demands of a population of elite tourists (Snyder and Davidson, 1994). By 2008, Southeast Florida (defined as the seven following counties: Indian River, St. Lucie, Martin, Palm Beach, Broward, MiamiDade, and Monroe) had a population of 6.2 million, larger than 34 of the 50 states (Ogburn, 2010). Miami-Dade was the $8^{\text {th }}$ largest county in the nation and the population had increased from 2.2 million in 2000 to an estimated 2.5 million in 2009 , an approximate $14 \%$ increase in population (US Census Bureau, 2010). As the population has increased, overall municipal water consumption has also been affected. In 2011, the MDC Water and Sewer District pumped an average of 305.7 million gallons per day (MGD) but is projected to use between 367 and 390 MGD by 2026.This projected range is is based on population change and water demand change between 2007 and 2011 (MDC, 2011). In that time, water demand actually decreased from 315.8 MGD to 305.7 MGD, over a $3 \%$ decrease, while the population actually increased nearly $1 \%$ in that time. This reduction equals a per capita water demand change from 143 to 134 in Gallons Per Capita per Day (GPCD). The high projection of 390 MGD assumes that 
water conservation efforts no longer apply while the lower projection of 367 MGD assumes they do. They both use the same projected 2026 service district population of 2.65 million, a $16 \%$ increase over the 2011 population of 2.28 million people.

With continued population growth, land development, current flood control measures and expected climate change, water allocation in MDC has become of major concern. There is increased competition among water users from municipal (residential, commercial, industrial and governmental uses), agricultural, and ecological sectors (Everglades National Park) as the demand exceeds the supply in many areas (Dzurik et. al., 1984).

Agriculture is the largest water user sector in Florida representing $48 \%$ of the State's total freshwater withdrawn in 2000 (Marella, 2004). Agricultural water use is comprised of irrigation, livestock watering and aquaculture (SFWMD, 2007). A time series of water withdrawal trends by supply category shows agricultural uses as being dominant for the period 1975 - 2005 (Fig 3).

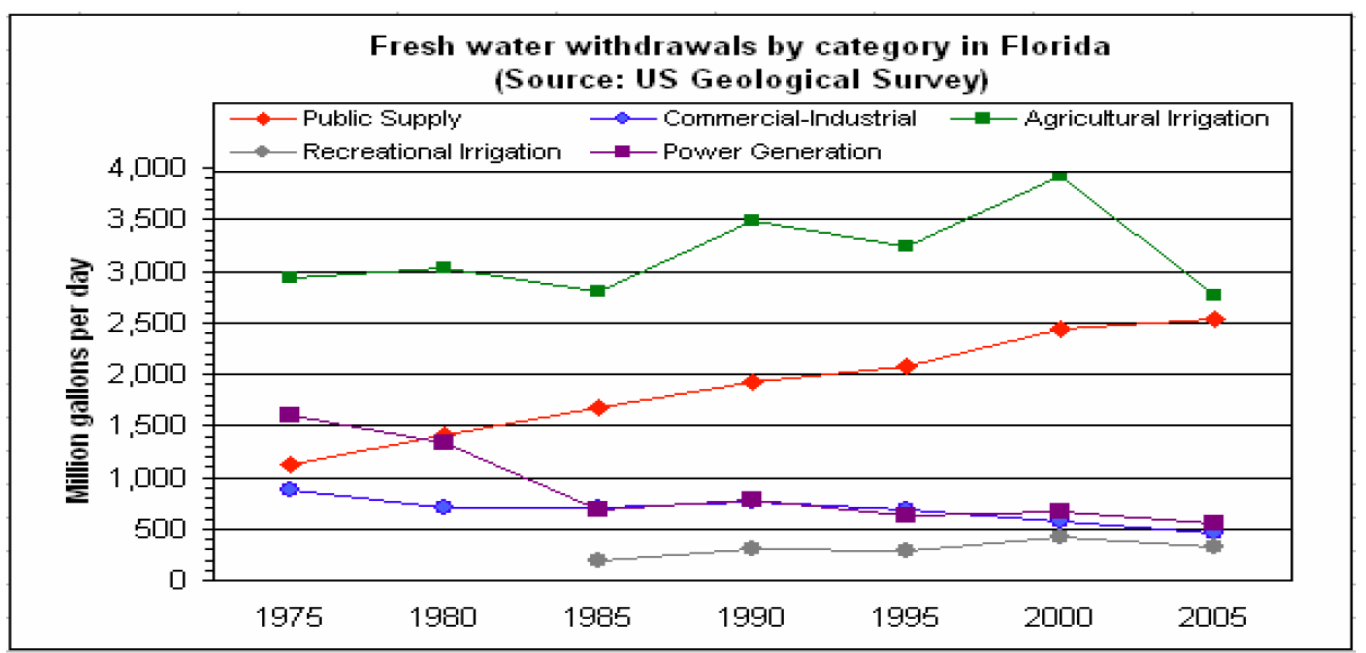

Figure 3 USGS water use trends 2005 (Excerpted from USGS, 2008) 
According to the USGS, total agricultural and public supply holds the largest share of freshwater withdrawal in 2005 (Fig. 3). Between 2000 and 2005, water withdrawals for agricultural irrigation dropped by about 1200 MGD, unlike the continuous rise of public water supply since 1975 .

The residential sector is primarily represented by Single Family (SF) and MultiFamily (MF) users. SF parcels are typically comprised of individually landscaped and irrigated yards. Government/public water usage represents the portion of water used in government buildings, parks and along roadways. Other non-residential water users may be offices, shops, retail businesses, warehouse and restaurants including light industrial manufacturing, etc. (MDWASD, 2005).

\subsection{Water Use}

Human beings have always utilized fresh water according to our needs (Gleick, 2003). Over time, developments in engineering and technological innovations of dams and irrigation canals have boosted agricultural production worldwide. According to Gleick (2003), urbanization of any area requires the advancement of sophisticated infrastructures to reach the water users along with an innovative system to remove the waste. A conventional focus on water use relied on infrastructure design and economic viability of water supply systems like constructing dams and aqueducts for water treatment and distribution facilities, whereas a modern approach of water use relies on water efficient technologies (Gleick, 2003). Fortunately, saving water around the house is significantly easier today than ever before. Modern design of toilets, showers and faucets 
are considered to be more efficient and can save many gallons per day of household water.

Primary thoughts by water managers on increased water use and supply infrastructure expansion were mainly based on socio-economic variables like population and economic growth (Gleick, 2003; Siklomanov and Rodda, 2004). Increases in population and economic growth cause a dramatic rise in water use. Later, it was realized that population and economic growth are not solely responsible for water use rise. Rock (1998) found a nonlinear relationship of water and economic growth by analyzing the GDP and per capita water withdrawal in 68 countries. Similar results were found by Gleick (2003).

Simple models of water demand simply take into account the amount of water used and the number of people using it. This allows the calculation of gallons per capita per day (gpcd). When estimating future demand, many simple models take expected future population growth and then multiply that with the current gpcd to derive a future estimated water demand. Though this may seem dangerously simplistic, Billing and Jones (2008) reported that the majority of water management agencies nationwide were applying this method to estimate future water demand. Furthermore, the Pacific Institute (2013) reported that less than half of water management agencies took into account land use change when making demand forecasts. The Pacific Institute reports that most water demand models actually overestimated water demand, some to a very large degree. For example, in 1965 Seattle Public Utilities predicted that by 1985 its water demand would increase from 150 Million gallons annually to 260 Million gallons annually. The actual water demand in 1985 was 160 Million Gallons annually (Pacific Institute, 2013), thus 
the forecast was eleven times higher than the actual increase over the 20 year period. Subsequent forecasts remained well over actual demand as well (Pacific Institute, 2013).

A land use based approach, therefore, is considered to be more appropriate compared to traditional population and economic growth model for water use study, especially in estimating the demand (Huo et al, 2006). For this conclusion, Huo et al, (2006) used the land use approach to prepare a long-range water supply facilities work plan for the city of Cape Coral in southwest Florida by linking land use and water billing data using ArcGIS software. SFWMD, as required in 2002 Legislation, has also made the land use based approach mandatory in order to have better coordination of water supply planning and land use planning in local government comprehensive plans (Huo et al, 2006). Despite these facts there is paucity of literature related to land use approach for water use study. Though using land use as the driver of water demand is not a universally embraced technique the methods used in this thesis, though laborious, offer a more nuanced and far less coarse derivation of water demand than a simple population forecast.

\subsection{Research Questions and Hypotheses}

As land use change is often proposed, planned for, or forecast, appending an associated water extraction scenario to such proposals, plans, and forecasts could be of great value to water managers as well as other policy and decision-makers.

Consequently, by better understanding past land use change and its associated water extraction fluctuations, water managers can better plan for future water needs across time, space, as well as economic sectors. This study aims to analyze land use change and its 
associated water use impacts in the Redland community of MDC. To be clear, this study is concerned only with human consumption of water, not other allocations that are involved with Everglades's restoration, water storage, conservation, or any other nonconsumptive uses. As Redland has a diversity of land uses and changes that are representative of all of MDC, understanding these changes in Redland can shed light on changes across the County and South Florida. Water use in Redland has shifted throughout the years, both by land use category and geographically. Therefore, this study especially focuses on identifying various parts of Redland that have exhibited an increased or decreased water demand. Estimated water demand "intensity" will also be measured in this study. This is defined as the gallons per day (GPD) per acre that is estimated for different land uses. The findings of this study will provide insight on land use change and its consequent impacts on water consumption trends in different sectors of Redland. The study has been guided by the following research questions:

- How has the widespread conversion of farmland to residential land uses affected the overall amount of water used in Redland?

- How has the average intensity of water demand per acre changed overall in Redland?

1. Specifically, what type of land conversions have resulted in greater intensity of water demand? Where are the areas of greatest intensity change?

2. How has the locus of water demand intensity shifted in Redland?

- How has the percentage of water demand allocated shifted by land use in the last 10 years? 


\subsubsection{Objectives}

The overall goal of this study is to analyze land use change and its associated impacts on water use in Redland.

Specifically:

- To compare Municipal vs. Agricultural water usage in Redland over time

- To study the water usage in different land categories of Redland and estimate the change in water demand

\subsubsection{Hypotheses}

Based on the results to the research questions cited above, I hypothesize the following:

- The conversion of agricultural lands to residential lands in Redland has resulted in an overall increase in water demand for Redland.

- Farmland that converts to residential lands results in an increase in water demand per acre.

- Areas of greatest water demand intensity change are in the Northeast corner (Richmond West) and the Southeast Corner (Naranja) due to the heavy conversion from farmland to residential development there.

- With increases in development, water demand has shifted from West to East within Redland.

- Residential water use has increased while agricultural water use has decreased. 
2. Methods

\subsection{Introduction}

The first and necessary step to answering the research questions in Chapter 1 was to implement a system of coding whereby each land use classification could receive water demand estimation. There were two main sources of data as well as two methods of estimating water demand. Two data sources were necessary because Redland covers two water jurisdictions: the MDC Water and Sewer District (WASD) as well as direct permitting for agriculture from the SFWMD. The first data sources were two appraiser shapefiles from MDC, one from 2001 and one from 2011. For agricultural land water demand estimations were dependent upon techniques developed by the SFWMD and USGS. Table 1 displays the different data sources and their purpose.

Table 1 Data Used to estimate water demand

\begin{tabular}{|l|l|l|l|}
\hline Data & Source & Purpose & Caveats \\
\hline $\begin{array}{l}\text { Appraiser } \\
\text { Shapefiles }\end{array}$ & $\begin{array}{l}\text { MDC } \\
\text { Appraiser }\end{array}$ & $\begin{array}{l}\text { To classify all non- } \\
\text { agricultural and non-public } \\
\text { lands according to water } \\
\text { estimation assumptions } \\
\text { provided by MDCWASD }\end{array}$ & $\begin{array}{l}\text { 2011 Data has } \\
\text { additional info } \\
\text { that assisted in } \\
\text { interpretation. } \\
\text { 2001 does not. }\end{array}$ \\
\hline $\begin{array}{l}\text { 2001 and 2011 } \\
\text { Land Use } \\
\text { Shapefiles }\end{array}$ & $\begin{array}{l}\text { MDC Planning } \\
\text { And Zoning }\end{array}$ & $\begin{array}{l}\text { Used to identify different } \\
\text { types of agricultural land } \\
\text { uses. }\end{array}$ & $\begin{array}{l}\text { Different } \\
\text { coding system } \\
\text { from appraiser } \\
\text { shapefiles. }\end{array}$ \\
\hline $\begin{array}{l}\text { Water estimation } \\
\text { document showing } \\
\text { both current and } \\
\text { old estimation } \\
\text { techniques } \\
\text { (Appendix 1) }\end{array}$ & MDC WASD & $\begin{array}{l}\text { To properly identify and } \\
\text { estimate water demand for all } \\
\text { non-agricultural and non- } \\
\text { public parcels in MDC }\end{array}$ & $\begin{array}{l}\text { The land use } \\
\text { classes } \\
\text { discussed in } \\
\text { document are } \\
\text { not identical } \\
\text { to those } \\
\text { classification } \\
\text { used by } \\
\text { appraiser. } \\
\text { Interpretation } \\
\text { necessary. }\end{array}$ \\
\hline
\end{tabular}




\begin{tabular}{|l|l|l|l|}
\hline $\begin{array}{l}\text { Percent irrigated } \\
\text { land }\end{array}$ & $\begin{array}{l}\text { USDA NASS } \\
(2002)\end{array}$ & $\begin{array}{l}\text { To calculate amount of } \\
\text { irrigated land in different } \\
\text { farmland categories for 2001 } \\
\text { LU data }\end{array}$ & $\begin{array}{l}\text { Average given } \\
\text { to all lands of } \\
\text { that type. }\end{array}$ \\
\hline $\begin{array}{l}\text { Percent Irrigated } \\
\text { Land }\end{array}$ & $\begin{array}{l}\text { USDA NASS } \\
\text { (2007) }\end{array}$ & $\begin{array}{l}\text { To calculate amount of } \\
\text { irrigated land in different } \\
\text { farmland categories for 2011 } \\
\text { Land Use data }\end{array}$ & $\begin{array}{l}\text { Average given } \\
\text { to all lands of } \\
\text { that type. }\end{array}$ \\
\hline
\end{tabular}

\subsection{Rendering of Data}

To estimate water demand across the study site, the different data sources had to be non-overlapping and assigned a water demand as calculated by gallons per day per acre or GPD per acre. To ensure non-overlapping areas, all those properties in the appraiser shapefiles that were either State or Federal owned lands as well as agricultural were removed from the shapefiles. Next, agricultural lands were analyzed from the land use shapefiles. Certain agricultural classifications (780 and 790) were given a value of zero as explained in Table 2. Whenever possible those zero values were supplemented by any findings in the appraiser shapefile to maximize the amount of possible data. Thus three shapefiles for each year were created.

\subsection{Municipal Water Estimation}

Using the data sources (Table 1) all of the shapefiles was coded with an estimated GPD per acre. In most cases, the given Acreage, rather than a recalculated acreage was given in order to more accurately reflect water demand intensity per acre. For example, a 100 acre property that only had $10 \%$ of its land area in Redland would keep its 100 acre status and thus not get a spuriously high GPD per acre value. Next, those properties in the appraiser shapefiles that were either State or Federal owned lands as well as 
agricultural were removed since those were analyzed in the Land use shapefiles provided by Planning and Zoning. Next, agricultural lands were analyzed from the land use shapefiles (as explained in 3.3). As shown in Table 2, certain classifications $(750,780$ and 790) were given a value of zero. Whenever possible those zero values were supplemented by findings in the appraiser shapefiles to maximize the amount of possible data. Thus three non-overlapping shapefiles for each year were created. To estimate water demand in the appraiser shapefiles the assumptions used by MDC WASD as shown in Appendix 1 were used. These assumptions often relied upon either square footage of a building or the number of units in a building. This is why it was necessary to use appraiser data rather than land use data from planning and zoning in order to estimate municipal water demand. Unfortunately, they both use different land use codes (See appendices 2 versus 4 ). As a further difficulty, the WASD uses different land use categories from the appraiser's office. Therefore, it was necessary to interpret and translate the information between Appendix 1 and 2. The resulting assumptions are found in Appendix 3. This Appendix identifies each County Land Use Code of the appraiser's office and gives a corresponding water estimation assumption as interpreted from Appendix 1. It is important to note that the 2011 Appraiser shapefile was supplemented by State Land Use Code information (Appendix 2) while the 2001 appraiser shapefile did not have such supplementation. Lastly, the water estimations from the WASD (Appendix 1) show deleted as well as non-deleted estimations. The deleted (shown as strike through text) text corresponds to 2001 water estimations based on land use while the non-deleted text corresponds to 2011 water estimations based on land use (Virginia Walsh, personal communication). The documents I received from 
WASD were accompanied by verbal guidance. Dr. Walsh explained that the deleted estimations were accurate for water demand in 2001 (deleted because they were old) while the non-deleted estimations were accurate for water demand in 2011 (non-deleted because they are current). These documents were delivered with those aforementioned portions struck through as deleted text. I did not make any changes to these documents. With water demand for each parcel calculated then water demand per acre could also be calculated and thus water demand intensity is assigned to each parcel.

\subsection{Estimated Water Demand for Agricultural Land Use Categories}

In this study, agricultural water demand estimates based on irrigated acreage, use coefficients, crop and soil type, and irrigation models were identified in USGS and SFWMD reports. Though it is possible to meter water in agricultural areas and therefore know the exact amount of water being used, most farms in MDC are not metered (Renken, et al. 2005). Furthermore, the data obtained from SFWMD that did offer actual metered data was often spread over several non-contiguous parcels and/or was not available in both time periods. Therefore, the SFWMD often estimates the amount of water being used in agricultural areas and this thesis reproduces that methodology.

Agricultural water demand is estimated by calculating evapotranspiration (ET) as well as certain crop coefficients. ET is necessary for the plant photosynthesis and increases with low humidity, high insolation, and high wind (Smajstrla, et. al, 2008). Therefore, average ET values vary over space and time and are therefore indicative of local climatic conditions. Thus, an estimation of ET values for MDC is performed by SFWMD to estimate irrigation needs. A modified form of the Braney-Criddle Equation 
that includes crop coefficients (Eq. 1) is used to make this estimation (Marella, 1999; Renken, et al. 2005). Though these estimations are old (1995), they are the most recent found that specifically make estimates for Miami-Dade County, broken down by different types of agricultural land uses. Though the specific modifications made to the BlaneyCriddle formulation by the researchers were not divulged (Marella, 1999; Renken, et al. 2005) the results of their calculations based on agricultural land use were presented in the research. Also, since Marella (1999) and Renken and colleages (2005) focused on different agricultural land uses, both are used to cover as many agricultural land uses as possible in MDC. Lastly, since the percent of irrigated land in both Row crops as well as Groves is important to estimate water demand the USDA National Agricultural Statistics Service was employed to discover the total percentage of Row Crops irrigated by acreage as well as Groves. This was calculated using the 2002 Agricultural Census for 2001 land use and the 2007 Agricultural Census for the 2011 land use data. Unfortunately, the results from the 2012 Census are as of yet not fully available. To be clear, I did not calculate the ET of these various areas in Redland, Marela (1999) as well as Renken and colleagues (2005) did this for all of MDC and I used their estimations in this research. Without more recent data, I assumed the same ET (from the findings of Marela 1999 and Renken et al. 2005) based on land use for both 2001 and 2011.

Since the Land Use data does not provide specific information regarding whether or not nurseries are using containers or are in the ground, the average of both Marella's (1999) and Renken and colleagues estimations were used. Finally, Renken and colleagues' (2005) estimations were used for golf courses while Marella's (1999) estimations for improved pasture and aquaculture were employed. Though golf courses 
and aquaculture do consume a great deal of water they comprise a very small amount of acreage in Redland and are therefore not major determinants in overall water demand. As for nurseries, they are very important but I did not have the data to differentiate between above ground and below ground nurseries in the same way that Renken and Marella did so I used the average of their percent irrigated area. If I was to assume the higher amount of irrigated area then each parcel would have a lower GPD per acre whereas if I were to assume the lower, then each parcel would have a higher GPD per acre. I could then take the higher or the lower of the above ground or below ground average water demands. Again, that would increase or decrease the GPD per acre for all nurseries. Lacking more specific information, I decided to just take the average of this range. More specific information would of course be helpful to make a more precise estimate.

Equation 1: The Blaney-Criddle Formulation

$\mathrm{ET}_{\mathrm{o}}=\mathrm{p} \cdot\left(0.46 \cdot \mathrm{T}_{\text {mean }}+8\right)$

Where:

$\mathrm{ET}_{\mathrm{o}}$ is the reference evapotranspiration $\left[\mathrm{mm} \mathrm{day}^{-1}\right]$ (monthly)

$\mathrm{T}_{\text {mean }}$ is the mean daily temperature $\left[{ }^{\circ} \mathrm{C}\right]$ given as $\mathrm{T}_{\text {mean }}=\left(\mathrm{T}_{\max }+\mathrm{T}_{\min }\right) / 2$

$\mathrm{p}$ is the mean daily percentage of annual daytime hours. 
Table 2 Translation and interpretation of Ag land classes in Appendix 4 according to SFWMD and USGS estimates of water demand per agricultural land use.

\begin{tabular}{|c|c|c|c|}
\hline $\begin{array}{l}\text { Ag type } \\
\text { by CLUC } \\
\text { (Appendix } \\
\text { 4) }\end{array}$ & $\begin{array}{l}\text { As identified } \\
\text { in Sources }\end{array}$ & $\begin{array}{l}\text { Percent of parcel area assumed to be } \\
\text { irrigated }\end{array}$ & $\begin{array}{l}\text { Renken } \\
\text { (million } \\
\text { gallons per } \\
\text { acre/day) }\end{array}$ \\
\hline $\begin{array}{l}710 \\
\text { (Groves) }\end{array}$ & $\begin{array}{l}\text { Fruit } \\
\text { Orchards }\end{array}$ & $\begin{array}{l}80.3 \% \text { irrigated in } 2001 \text { (USDA 2002) } \\
79.3 \% \text { irrigated in } 2011 \text { (USDA 2007) }\end{array}$ & $0.00198365 \mathrm{~b}$ \\
\hline $\begin{array}{l}720 \text { (Row } \\
\text { and Field } \\
\text { Cropland) }\end{array}$ & Row Crops & $\begin{array}{l}87.6 \% \text { irrigated in } 2001 \text { (USDA 2002) } \\
83.4 \% \text { irrigated in } 2011 \text { (USDA 2007) }\end{array}$ & $0.00127081 \mathrm{~b}$ \\
\hline $\begin{array}{l}730 \\
\text { (Pasture) }\end{array}$ & $\begin{array}{l}\text { Improved } \\
\text { Pasture }\end{array}$ & $10 \%$ & $0.00089337 \mathrm{a}$ \\
\hline $\begin{array}{l}731 \text { Horse } \\
\text { Training }\end{array}$ & $\begin{array}{l}\text { Improved } \\
\text { Pasture }\end{array}$ & $10 \%$ & $0.00089337 \mathrm{a}$ \\
\hline $\begin{array}{l}732 \\
\text { (Poultry) }\end{array}$ & $\begin{array}{l}\text { Improved } \\
\text { Pasture }\end{array}$ & $10 \%$ & $0.00089337 \mathrm{a}$ \\
\hline $\begin{array}{l}750 \\
\text { Fallow }\end{array}$ & & $0 \%$ & 0 \\
\hline $\begin{array}{l}760 \text { (Plant } \\
\text { Nurseries) }\end{array}$ & $\begin{array}{l}\text { Ornamental } \\
\text { Container } \\
\text { AND } \\
\text { Ornamental } \\
\text { Field Growth } \\
\text { Problem (in } \\
2001 \text { can't } \\
\text { differentiate) }\end{array}$ & $\begin{array}{l}90 \% \text { for container } b \\
98 \% \text { for field a } \\
\text { Average is } 94 \%\end{array}$ & $\begin{array}{l}\text { Container } \\
0.00206117 \mathrm{~b} \\
\text { Field Grown } \\
0.00196995 \mathrm{a} \\
\\
\text { Average is: } \\
0.00201556\end{array}$ \\
\hline $\begin{array}{l}770 \text { (Fish } \\
\text { Farms) }\end{array}$ & & & $0.0037197 \mathrm{a}$ \\
\hline $\begin{array}{l}780 \text { Farm } \\
\text { Storge }\end{array}$ & & 0 & 0 \\
\hline $\begin{array}{l}790(\mathrm{Ag} \\
\text { Other })\end{array}$ & & 0 & 0 \\
\hline $\begin{array}{l}\text { Golf } \\
\text { Course }\end{array}$ & & $80.6 \% \mathrm{~b}$ & $0.00257873 \mathrm{~b}$ \\
\hline
\end{tabular}

a( Marella, R.L., 1999); b(Renken, R.A.et.al, 2005) 
With water demand for each agricultural parcel calculated then water demand per acre could also be calculated and thus water demand intensity is assigned to each parcel.

\subsection{Raster Analysis}

For analysis each shapefile was converted to a raster grid at 30 meter resolution. The 2001 rasters were then mosaicked into one raster and the same was done for the 2011 rasters. Map Algebra was then used to subtract 2011 water demand intensity from 2001. This reveals the areas in Redland where GPD per acre has increased or decreased. Then the 2001, 2011, and Water difference rasters were combined so that all the information for each cell was contained. There were 673 unique land use change combinations between 2001 and 2011 (including no change). When accounting for the more specific appraiser information that allowed for the GPD per acre to be calculated, and when this information is combined into a new raster, then there are 9887 combinations of land use change coupled with water demand change. Therefore, an exhaustive accounting of these 9887 combinations of change is not tenable. However, by focusing on: a) only those areas where land use actually changed; $b$ ) focusing on those combinations of land use changes (LUC) that account for the greatest amount of LUC; and c) focusing on those situations which resulted in the greatest water demand change, then the results can be more easily managed.

Due to the rasterization and the arbitrary imposition of a grid over more precise vector data, errors are bound to occur. Therefore, certain parts of canals and other water sites were assigned water demand values. As for Parks, many of these were given a value of zero since most of this acreage is not being irrigated but the category was kept because 
golf courses and cemeteries (which were treated as golf courses) were in this category. As for vacant land, much of this was given zero if the appraiser office showed no buildings on site; however, if there were buildings on the site then they were assigned appropriate values according to the table. The reason two separate files were used is because the appraiser files had more information regarding building square footage, bedrooms, bathrooms, etc. However, the County land use shapefiles had more categories of land use data to choose from and thus was a richer dataset. This was therefore used for Agricultural data. To maintain consistency in overall land use analysis only the County land use shapefiles are shown and analyzed. Again, there are different systems as well as other forms of disagreement between County land use shapefiles and the appraiser shapefiles but both were necessary in order to complete an adequate analysis.

The application of this methodology resulted in a rich raster dataset where each 30 meter cell contains:
A) Land use in 2001;
B) Land Use in 2011;
C) GPD per acre for 2001;
D) GPD per acre for 2011; and
E) The difference in GPD per acre between 2001 and 2011.

Due to the large number of unique combinations of land use change coupled with water demand change, the data was explored by sorting and summarizing to discover those land use changes that were most meaningful to water demand change. These important land uses were discovered by first aggregating the land use classes into 10 categories. Some of these land categories comprise large acreage, such as Parks and 
Open Space, but have a small water demand while others have a high water demand per acre, such as Industrial, but comprise very small acreage in Redland. Therefore, land categories including Parks and Open Space, Vacant, Commercial, Industrial, Institutional, and Hotel were aggregated together into a category called Other Land. Though accounting for over $1 / 3$ of the total acreage, Other Land is calculated to have merely $6.27 \%$ of the estimated water demand in 2011 . Therefore, land uses that comprised small acreages and/or land uses that comprised large acreages but were estimated to have little water demand were in some aspects of the analysis grouped together so that those more important land uses (as far as water demand is concerned) could be more easily identified and focused upon. Doing this reveals that there are three large water using categories: Nurseries, Row and Field Cropland, and Groves. As will be seen, these categories also underwent a great deal of land use change. Other agricultural categories including Poultry, Aquaculture, Horse Stables, Farm Storage, and Fallow, were aggregated together since comprise only a small fraction of both agricultural acreage as well as total water demand.

\subsection{Mean Weight}

With the data in raster format then spatial analysis can be performed. By weighting each cell with its water demand and then using a weighted mean algorithm the center of water demand in both 2001 and 2011 were calculated. 


\section{Results}

To orient the study area, Fig. 4 offers a 2001 map of land uses that are most relevant to water demand change while Fig. 5 shows the same 2011 land uses. Fig. 6 and 7 show water demand intensity in Redland in both years, respectively. The 10 general land use categories for 2001 and 2011 are shown in Tables 3 and 4, respectively. Each specific agricultural category was analyzed for water demand as seen in Tables 5 and 6 .

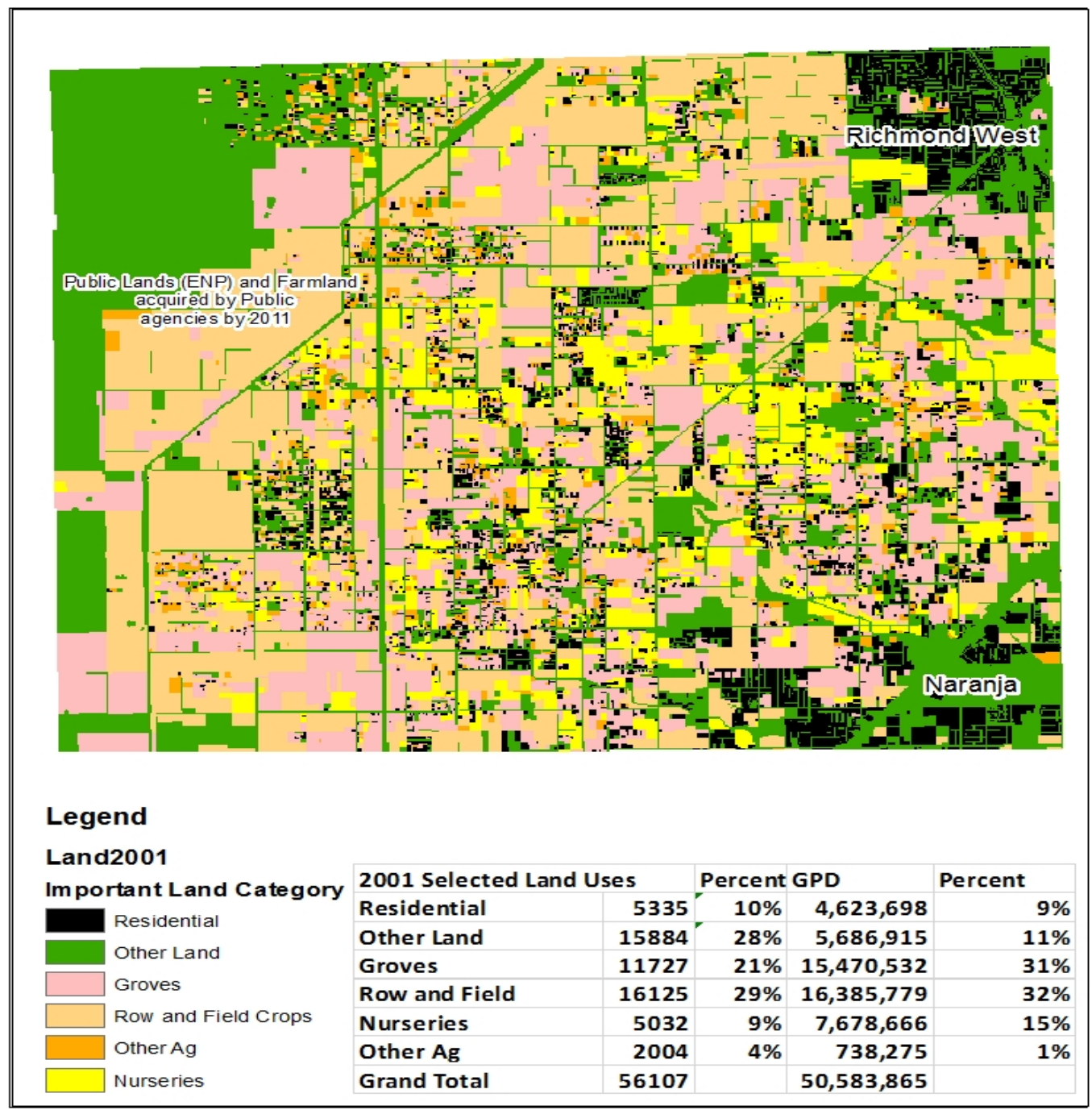

Figure 4 Redland Land Use 2001 (Note: This is a snapshot of land use in Redland in 2001, along with a table that depicts acreage in each category as well as the percentage that acreage represents of total acreage of all land in Redland.) 


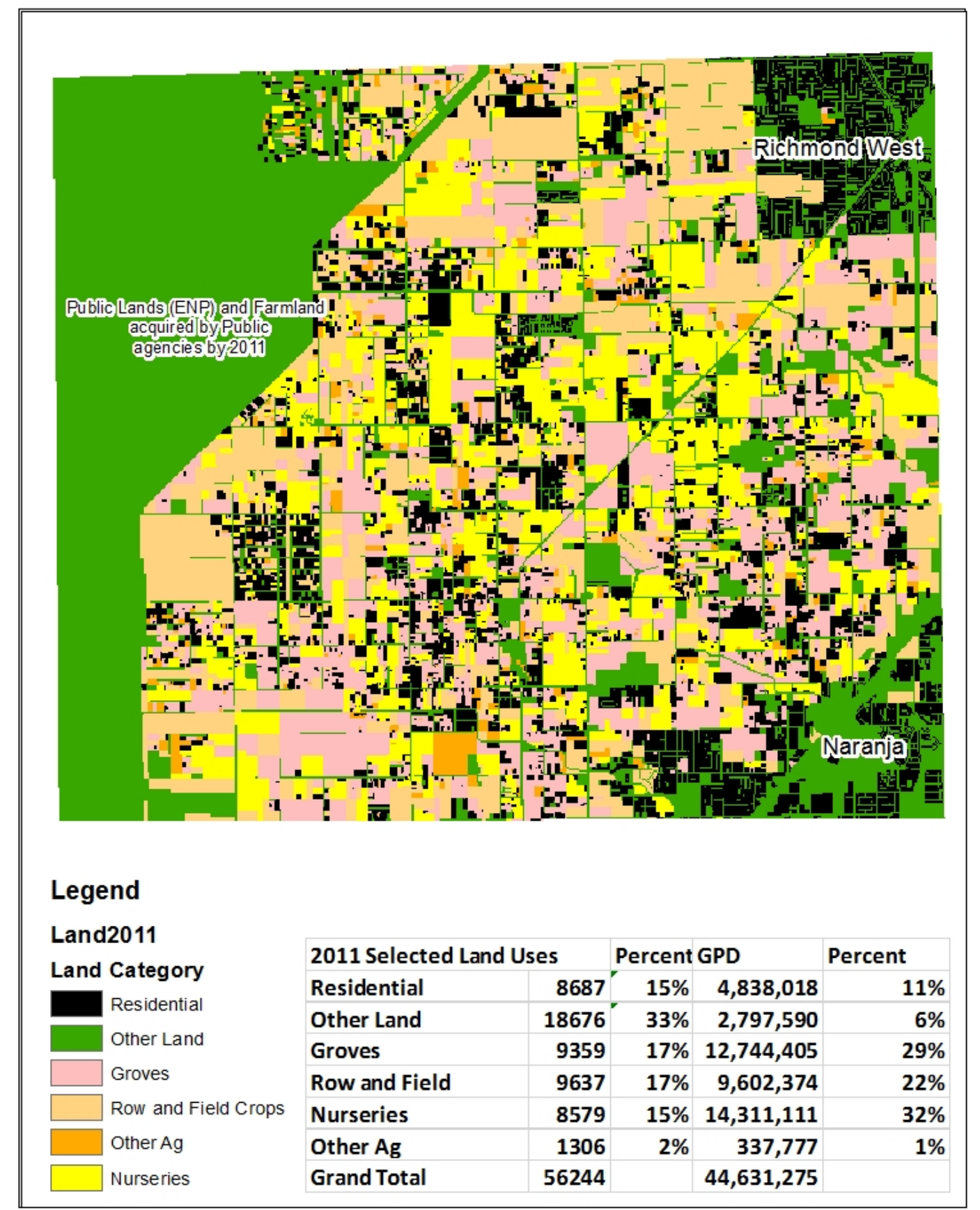

Figure 5 Redland Land Use 2011 (Note: This is a snapshot of land use in Redland in 2011, along with a table that depicts acreage in each category as well as the percentage that acreage represents of total acreage of all land in Redland.) 


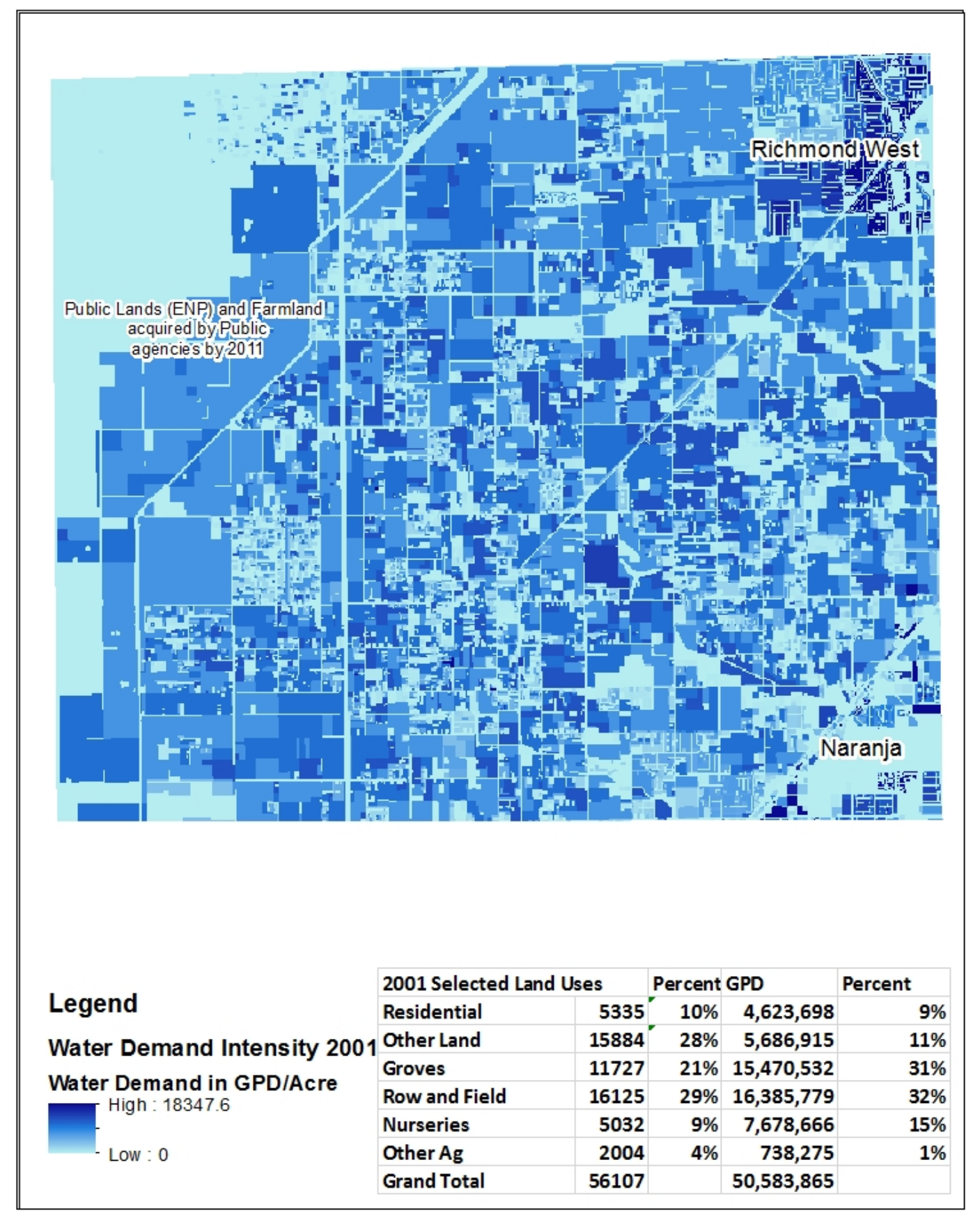

Figure 6 Redland Estimated Water Demand Intensity 2001 


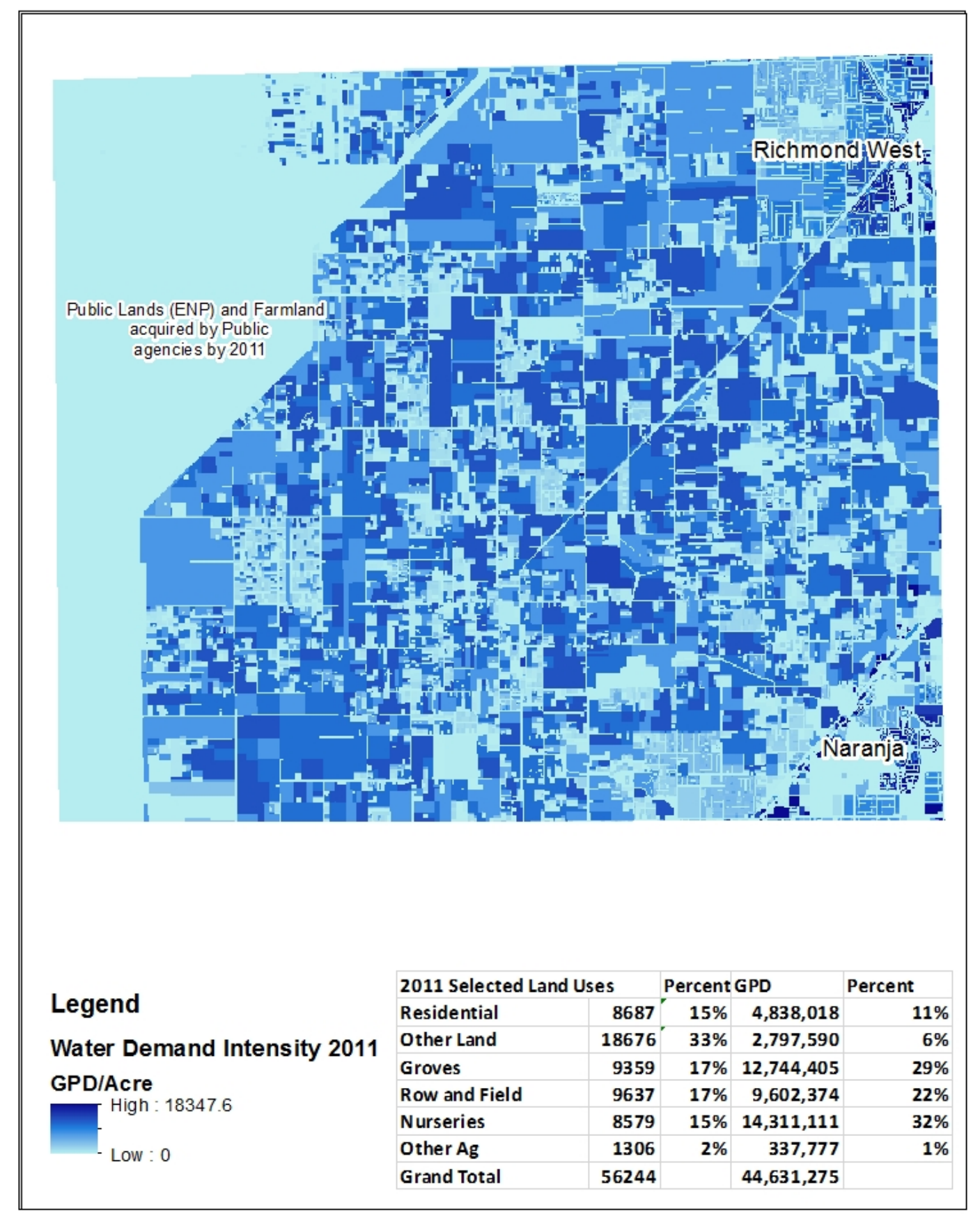

Figure 7 Redland Estimated Water Demand Intensity 2011 
Table 32001 General Land Use in Redland (Generalization guidance found in Appendix 4)

\begin{tabular}{|l|r|r|r|r|r|}
\hline 2001 Generalized Lan Acreage & Percent GPD & Percent & GPD/Acre \\
\hline Residential & 5335 & $10 \%$ & $4,623,698$ & $9 \%$ & 867 \\
\hline Commercial & 174 & $0 \%$ & 83,341 & $0 \%$ & 479 \\
\hline Hotel & 8 & $0 \%$ & 13,327 & $0 \%$ & 1666 \\
\hline Industrial & 122 & $0 \%$ & 98,226 & $0 \%$ & 805 \\
\hline Institutional & 247 & $0 \%$ & 86,644 & $0 \%$ & 351 \\
\hline Parks & 5327 & $9 \%$ & 396,114 & $1 \%$ & 74 \\
\hline Roads and Util & 4808 & $9 \%$ & $2,366,160$ & $5 \%$ & 492 \\
\hline Agriculture & 34888 & $62 \%$ & $40,273,252$ & $80 \%$ & 1154 \\
\hline Vacant & 4455 & $8 \%$ & $2,366,160$ & $5 \%$ & 531 \\
\hline Water & 743 & $1 \%$ & 276,943 & $1 \%$ & 373 \\
\hline Total & 56107 & & $50,583,865$ & & \\
\hline
\end{tabular}

Table 42011 General Land Use in Redland (Generalization guidance found in Appendix 4)

\begin{tabular}{|l|r|r|r|r|r|}
\hline 2011 Generalized Lan & Acres & Percent GPD & Percent & GPD/Acre \\
\hline Residential & 8687 & $15 \%$ & $4,838,018$ & $11 \%$ & 557 \\
\hline Commercial & 241 & $0 \%$ & 303,626 & $1 \%$ & 1260 \\
\hline Hotel & 6 & $0 \%$ & 3,726 & $0 \%$ & 621 \\
\hline Industrial & 127 & $0 \%$ & 65,082 & $0 \%$ & 512 \\
\hline Institutional & 358 & $1 \%$ & 120,651 & $0 \%$ & 337 \\
\hline Parks & 5002 & $9 \%$ & 423,998 & $1 \%$ & 85 \\
\hline Roads and Util & 4386 & $8 \%$ & $1,485,882$ & $3 \%$ & 339 \\
\hline Agriculture & 28881 & $51 \%$ & $36,995,667$ & $83 \%$ & 1281 \\
\hline Vacant & 7830 & $14 \%$ & 206,375 & $0 \%$ & 26 \\
\hline Water & 726 & $1 \%$ & 188,250 & $0 \%$ & 259 \\
\hline Total & 56244 & & $44,631,275$ & & \\
\hline
\end{tabular}


Table 52001 Specific Agricultural Land Use in Redland (Categories specified in Appendix 4)

\begin{tabular}{|c|c|c|c|c|c|c|}
\hline 2001 Specific Ag Categories & Acres & Per Ag & Per Overall & GPD & Per Ag & Per Overall \\
\hline Groves & 11727 & $34 \%$ & $21 \%$ & $15,470,532$ & $38 \%$ & $31 \%$ \\
\hline Row and Field & 16125 & $46 \%$ & $29 \%$ & $16,385,779$ & $41 \%$ & $32 \%$ \\
\hline Pasture & 229 & $1 \%$ & $0 \%$ & 83,511 & $0 \%$ & $0 \%$ \\
\hline Horse Training & 830 & $2 \%$ & $1 \%$ & 265,379 & $1 \%$ & $1 \%$ \\
\hline Poultry & 52 & $0 \%$ & $0 \%$ & 14,244 & $0 \%$ & $0 \%$ \\
\hline Fallow & 409 & $1 \%$ & $1 \%$ & 98,438 & $0 \%$ & $0 \%$ \\
\hline Nurseries & 5032 & $14 \%$ & $\mathbf{9 \%}$ & $7,678,666$ & $19 \%$ & $15 \%$ \\
\hline Fish Farms & 20 & $0 \%$ & $0 \%$ & 50,308 & $0 \%$ & $0 \%$ \\
\hline Farm Storage & 418 & $1 \%$ & $1 \%$ & 214,419 & $1 \%$ & $0 \%$ \\
\hline Other Ag & 46 & $0 \%$ & $0 \%$ & 11,976 & $0 \%$ & $0 \%$ \\
\hline Total & 34888 & & & $40,273,252$ & & \\
\hline
\end{tabular}

Table 62011 Specific Agricultural Land Use in Redland (Categories specified in Appendix 4)

\begin{tabular}{|l|r|r|r|r|r|r|}
\hline Go11 Specific Ag Categories Acres & Per Ag & Per Overall & GPD & Per Ag & Per Overall \\
\hline Groves & $\mathbf{9 3 5 9}$ & $\mathbf{3 2 \%}$ & $\mathbf{1 7 \%}$ & $\mathbf{1 2 , 7 4 4 , 4 0 5}$ & $\mathbf{3 4 \%}$ & $\mathbf{2 9 \%}$ \\
\hline Row and Field & $\mathbf{9 6 3 7}$ & $\mathbf{3 3 \%}$ & $\mathbf{1 7 \%}$ & $\mathbf{9 , 6 0 2 , 3 7 4}$ & $\mathbf{2 6 \%}$ & $\mathbf{2 2 \%}$ \\
\hline Pasture & $\mathbf{2 1 4}$ & $\mathbf{1 \%}$ & $\mathbf{0 \%}$ & $\mathbf{5 9 , 1 4 6}$ & $\mathbf{0 \%}$ & $\mathbf{0 \%}$ \\
\hline Horse Training & $\mathbf{3 3 9}$ & $\mathbf{1 \%}$ & $\mathbf{1 \%}$ & $\mathbf{8 9 , 0 5 6}$ & $\mathbf{0 \%}$ & $\mathbf{0 \%}$ \\
\hline Poultry & $\mathbf{9}$ & $\mathbf{0 \%}$ & $\mathbf{0 \%}$ & $\mathbf{6 3 4}$ & $\mathbf{0 \%}$ & $\mathbf{0 \%}$ \\
\hline Fallow & $\mathbf{2 8 4}$ & $\mathbf{1 \%}$ & $\mathbf{1 \%}$ & $\mathbf{4 7 , 4 0 9}$ & $\mathbf{0 \%}$ & $\mathbf{0 \%}$ \\
\hline Nurseries & $\mathbf{8 5 7 9}$ & $\mathbf{3 0 \%}$ & $\mathbf{1 5 \%}$ & $\mathbf{1 4 , 3 1 1 , 1 1 1}$ & $\mathbf{3 9 \%}$ & $\mathbf{3 2 \%}$ \\
\hline Fish Farms & $\mathbf{1 1}$ & $\mathbf{0 \%}$ & $\mathbf{0 \%}$ & $\mathbf{2 9 , 1 1 8}$ & $\mathbf{0 \%}$ & $\mathbf{0 \%}$ \\
\hline Farm Storage & $\mathbf{2 7 4}$ & $\mathbf{1 \%}$ & $\mathbf{0 \%}$ & $\mathbf{9 6 , 4 9 1}$ & $\mathbf{0 \%}$ & $\mathbf{0 \%}$ \\
\hline Other Ag & 175 & $\mathbf{1}$ & $\mathbf{0 \%}$ & $\mathbf{1 5 , 9 2 3}$ & $\mathbf{0 \%}$ & $\mathbf{0 \%}$ \\
\hline Total & $\mathbf{2 8 8 8 1}$ & & & $\mathbf{3 6 , 9 9 5 , 6 6 7}$ & & \\
\hline
\end{tabular}

Not surprisingly, many areas in Redland were persistent in their land use and thus the no major change category comprises a large amount of acreage. Nevertheless, over 2600 acres of agricultural land was converted to residential in this 10 year period while over 5300 other agricultural acres were converted to Other Land. This is largely due to the acquisition of farmland in the Western portion of Redland by the SFWMD for the purposes of creating a water conservation and buffer area for Everglades National Park. 
In total, over 6000 net acres of agricultural land were converted to something else from 2001 to 2011, a 17\% drop in acreage (net is used because some lands have converted into agriculture, etc.).

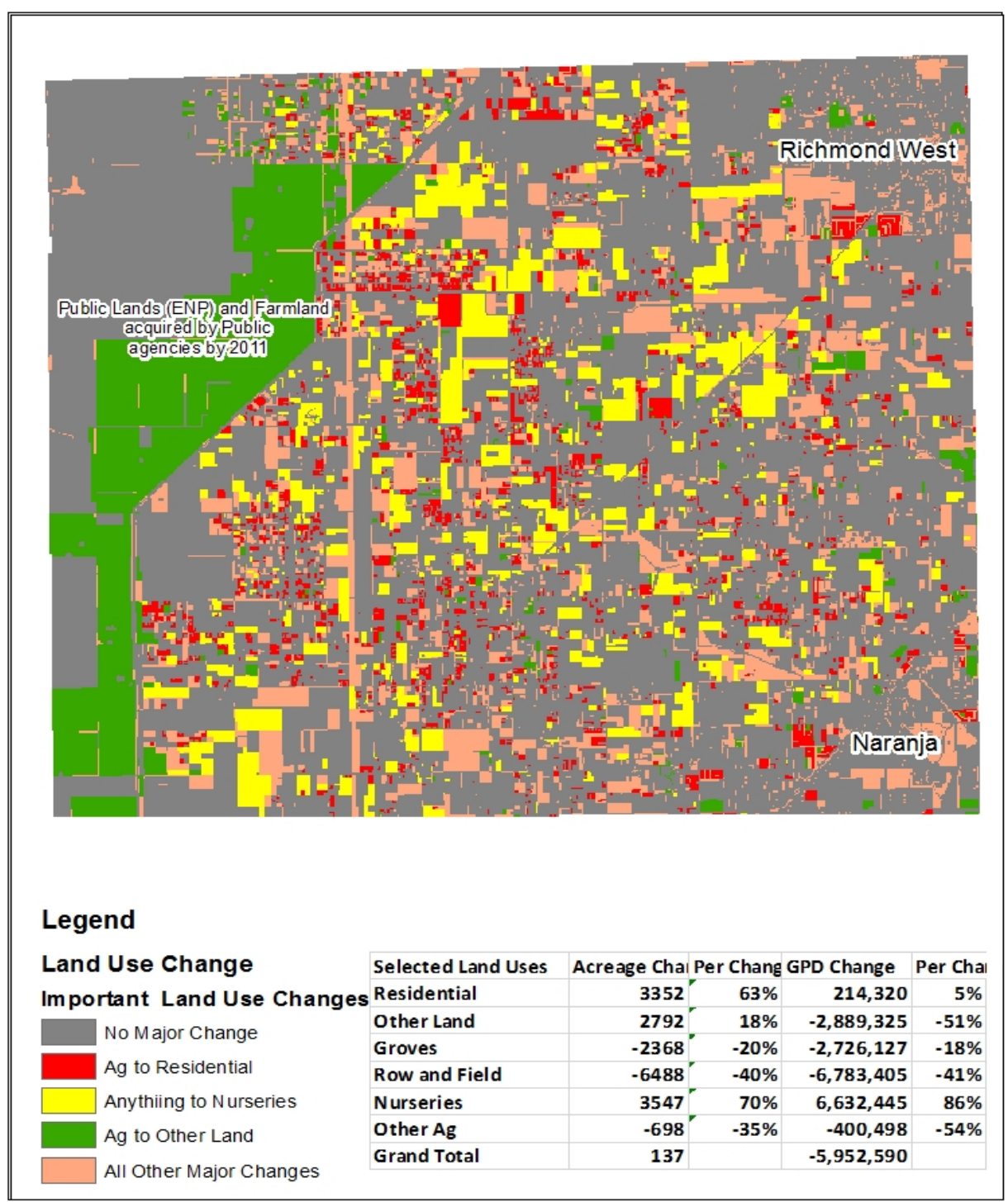

Figure 8 Major Land Use Changes in Redland 2001 to 2011 (Note: By identifying those land use changes that also were responsible for the greatest water demand changes, this map depicts the most important changes in land use. Areas of No Major Change are either the same land use code for each time period or it is a very similar land use code (one type of commercial code to another type of commercial code, for example). These areas, therefore, are listed as No Major Change.) 
Fig. 9 shows water demand change across Redland while Fig. 10 depicts those land use changes associated with the greatest decreases in water demand. Due to the large acquisitions, Row and Field Crops to Other as well as Groves to Other are together responsible for over half of all land use changes that resulted in decreased water demand. Other notable changes include changes from Groves to Row and Field Cropland, Nurseries to Row and Field Cropland as well as Row and Field Crops to Other Ag. Together, however, these three Land Use changes still consist of only about 7\% of all land use changes that resulted in decreased water demand. The total GPD decrease listed (over 9 million GPD) consists only of those decreases that are associated with land use change. It is important to understand that due to changes in irrigated area or changes in WASD estimations between 2001 and 2011, certain lands can remain unchanged between 2001 and 2011 and yet have different water demand estimations. As for those land use changes that resulted in water increases (Fig. 11), by far the most important is Row and Field Crop to Nurseries, which by itself resulted in nearly one third of all water increases associated with land use change. Other Land to Nurseries as well as Groves to Nurseries also contributes to over $16 \%$ of all water increases associated with land use change. Other to Groves and Other to Row contribute $8.5 \%$ each towards water increases associated with land use change. 


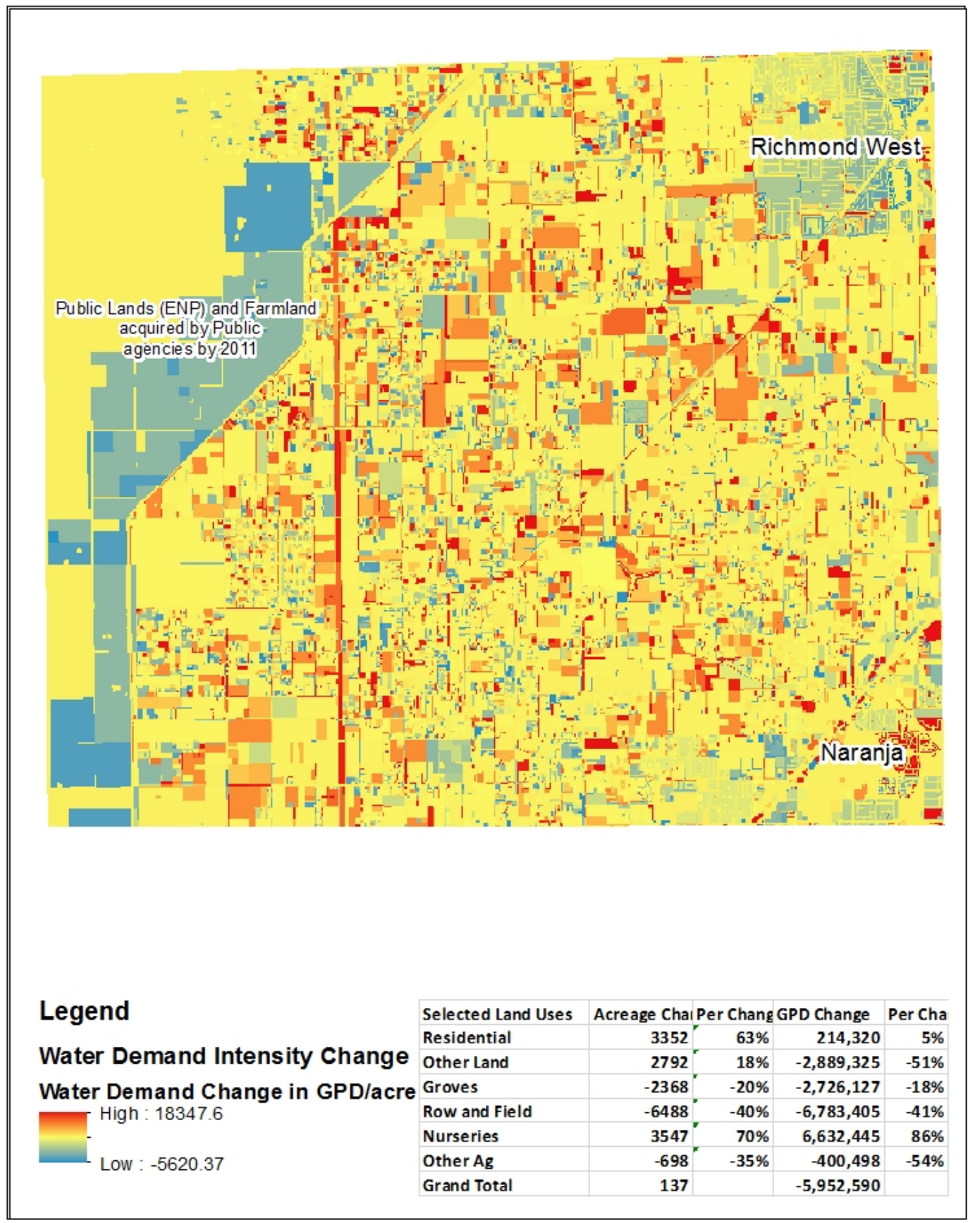

Figure 9 Water Demand Change in Redland from 2001 to 2011 (Note: \% Change category refers to the percentage increase or decrease in total water demand for that category from 2001 to 2011 . Therefore, total water demand for nurseries increased $86.37 \%$, etc. Table does not reflect all GPD change but only those associated with land use changes.) 
Table 7 Land Changes Leading to Greatest Water Decrease in GPD (Note: Total only includes all water demand decreases associated with land use change.)

\begin{tabular}{|l|r|r|r|r|r|}
\hline Land Use Change & Decrease GPD per Acre & Acres & Total GPD Decrease \% of Total Decrease \\
\hline Row to Other & -1077 & 3,135 & $-3,377,065$ & $-37 \%$ \\
\hline Grove to Other & -1516 & 1,570 & $-2,379,612$ & $-26 \%$ \\
\hline Grove to Row & -532 & 580 & $-308,560$ & $-3 \%$ \\
\hline Nurseries to Row & -833 & 228 & $-189,924$ & $-2 \%$ \\
\hline Row to Other Ag & -1113 & 128 & $-142,464$ & $-2 \%$ \\
\hline Total (including those not listed) & & & $-9,230,731$ & \\
\hline
\end{tabular}

\section{Land Changes leading to greatest Water Decrease in}

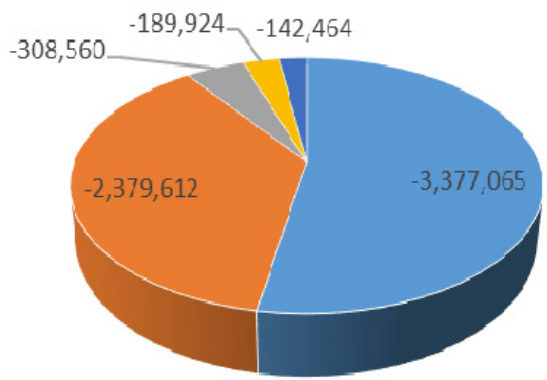

- Row to Other "Grove to Other "Grove to Row "Nurseries to Row " Row to Other Ag

Figure 10 Land Changes associated with greatest water demand decreases in Redland 
Table 8 Land Changes Leading to Greatest Water Increase in GPD (Note: Total only includes all water demand increases associated with land use change.)

\begin{tabular}{|l|r|r|r|r|r|}
\hline LU Change & Increase GPD per Acre & ACRES & Total GPD Increase & of Total Increase \\
\hline Other to Groves & 1339 & 372 & 498,359 & $9 \%$ \\
\hline Other to Row & 986 & 505 & 497,975 & $8 \%$ \\
\hline Other to Nurseries & 1653 & 439 & 725,674 & $12 \%$ \\
\hline Groves to Nurseries & 300 & 745 & 223,500 & $4 \%$ \\
\hline Row to Groves & 458 & 781 & 357,698 & $6 \%$ \\
\hline Row to Nurseries & 872 & 2168 & $1,889,910$ & $32 \%$ \\
\hline Total (including those not listed) & & & $5,859,556$ & \\
\hline
\end{tabular}

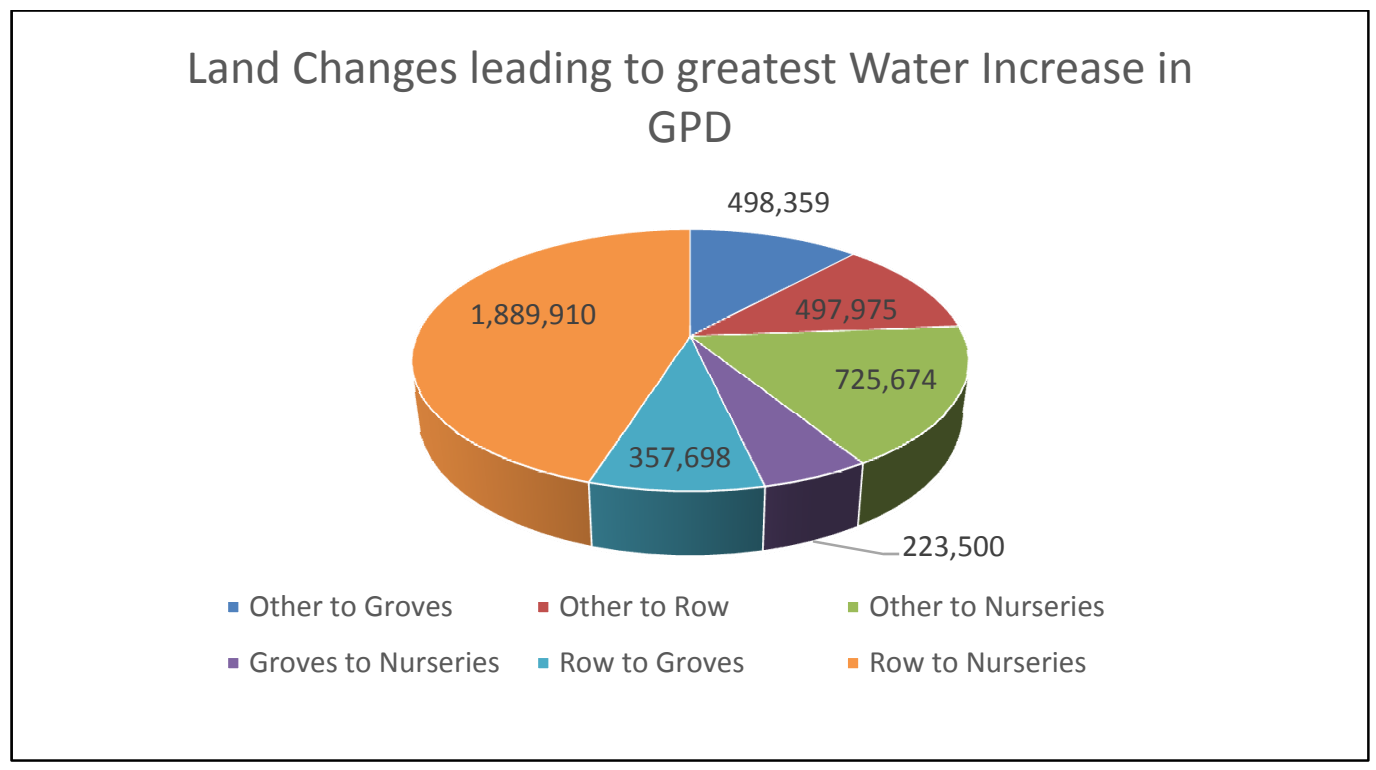

Figure 11 Land Changes associated with greatest water demand increases in Redland

The large proliferation of nurseries from 2001 to 2011 is an important area of focus. During this time, there was a net $41 \%$ increase in acreage dedicated to nurseries. By 2011, there were over 8500 acres so dedicated, mostly distributed in the central portion of Redland. Though, this is still only around $16.5 \%$ of all land area in Redland, by 2011 Nurseries, with their high GPD per acre, accounted for $1 / 3$ of all water demand 
in Redland (Table 6). Nearly $80 \%$ of all new nursery acreage came from either Row and Field Cropland or Groves. Thus, with the acquisitions in the West by SFWMD, the conversion to nurseries in the center, and the development in the East, Row and Field Cropland decreased by $40 \%$ while Groves decreased by $20 \%$. Though overall agricultural land decreased by over $17 \%$ in the ten year period, average GPD per acre of agricultural land increased from 1154 to 1281 , an $11 \%$ increase, mostly due to the increase in nurseries. This somewhat attenuates what would be a more drastic drop in overall water demand in the area and thus there is only an $8 \%$ decrease in agricultural water demand.

Results indicate that greater residential development in the area leads, in most cases, to a decrease in water demand. Over 2600 acres of agricultural land were converted to residential land, although other agricultural lands were created at this time as well, resulting in an average GPD per acre decrease of 265 for all such lands converted. Multiplying by the acreage indicates that nearly 700,000 GPD of water was saved by this conversion. Of course, certain conversion resulted in increases. For example, row and field cropland converting to an apartment complex will result in an increase in water demand per acre. However, the same farm converting to a single family home development results in less water demand. All agricultural conversion to single family home parcels resulted in an average decrease of 280 GPD per acre of all such lands converted.

Lastly, the results examining the Mean Weighted Center (or locus) of water demand, shown in Figure 12, show that from 2001 to 2011 the locus of water use has shifted only 1968 feet South and West of the 2001 locus (Fig. 9). The loss of farmland to 
SFWMD pushed it east while the proliferation of nurseries in the center of Redland caused the locus to stay more centralized, thus not causing a radical shift. Understanding which way water demand is moving could allow managers and planners to forecast future infrastructure improvements.

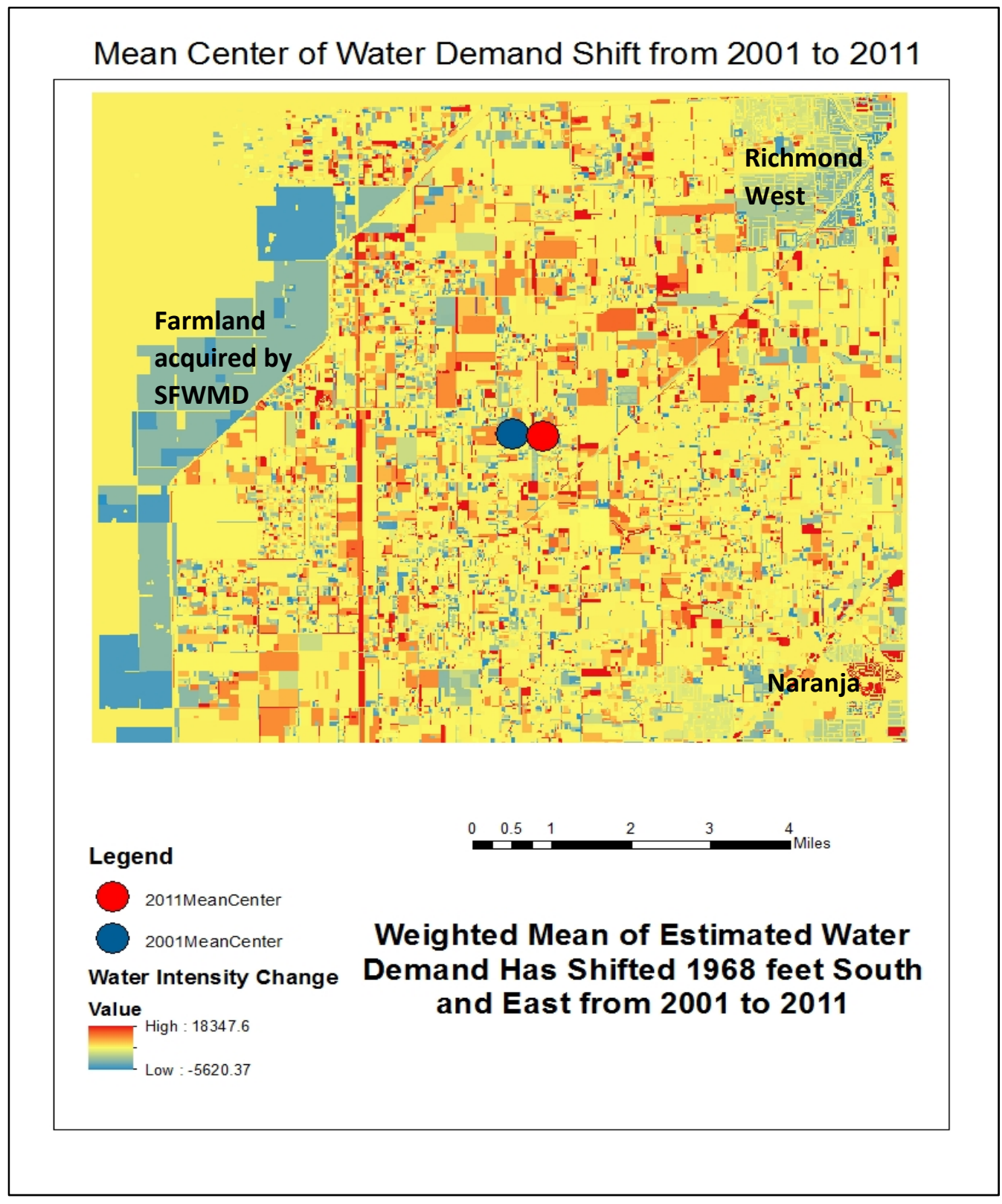

Figure 12 Locus Shift of Water Demand in Redland from 2001 to 2011 
As for the general land use analysis, in both 2001 and 2011, all general categories other than agriculture and residential, played a small part in water demand. However, by examining Table 9 changes by general land use category can be observed. Though, residential water demand increased by nearly $5 \%$, the amount of acreage dedicated to residential uses increased by $63 \%$. This can be explained due to a downward estimate of many residential land uses by the WASD, which resulted in a lower estimation for most residences. The WASD has said that apparently citizens are becoming more water conscious, and this is responsible for the drop (Virginia Walsh, personal communication). Commercial acreage increased by $39 \%$ yet GPD increased over $260 \%$. This is most likely due to the fact that commercial GPD is calculated by the size of the buildings and not the acreage of the parcel. Conversions to more intense commercial uses may also have played a part. Hotels decreased only slightly in acreage but far more in GPD and this can be explained by an overall loss of rooms since GPD for hotels is calculated per room. Though, industrial acreage increased its GPD actually decreased due to changes within industrial categories, particularly to low water using warehouses. Institutional increases in water demand kept largely in pace with increases in acreage. Though parks actually lost acreage their water usage increased. This can be explained due to the fact that this category contains cemeteries, golf courses, and private clubs and marinas and there was an increase in some of these facilities, despite the overall loss of this category. Other public lands in this category were not assigned any water demand. Roads and Utilities also include many facilities involved with infrastructure or utilities and these buildings were assigned water values. The loss of land can largely be attributed to the conversion of a utility corridor to agricultural uses found in the Western third of Redland. 
The power lines are still there but the land below them is now being farmed. Vacant lands also increased by $75 \%$ yet had a decrease in water demand by over $90 \%$. Lastly, the water category, which also can include adjacent facilities, showed a certain water demand. All three of these categories: Roads and Utilities, Vacant, and Water exhibit this difficult to explain behavior because the 2001 Appraiser data and the 2001 Land Use data have different classification methods as well as some disagreement. For example, certain areas classified as Vacant in 2001 land use data actually had single family homes on them in the appraiser data and were therefore considered to have water demand. By 2011, many of these lands were properly assigned to residential or other appropriate land uses, thus reducing disagreement between the two 2011 data files. Also, all buildings were considered to have some sort of water demand (bathrooms) and certain parcels on these three categories had buildings. Lastly, as explained in Chapter 3, there is always a certain amount of error when converting from vector to raster and therefore certain cells, a small number, contain both a road classification as well as a water demand that is an artifact from an adjacent land use.

Table 9 Land Use and Water Use Change by Generalized Land Use Category

\begin{tabular}{|l|r|r|}
\hline General Land Uses & Acreage change & GPD Change \\
\hline Residential & 3352 & 214,320 \\
\hline Commercial & 67 & 220,285 \\
\hline Hotel & -2 & $-9,601$ \\
\hline Industrial & 5 & $-33,144$ \\
\hline Institutional & 111 & 34,007 \\
\hline Parks & -325 & 27,884 \\
\hline Roads and Util & -422 & $-880,278$ \\
\hline Agriculture & -6007 & $-3,277,585$ \\
\hline Vacant & 3375 & $-2,159,785$ \\
\hline Water & -17 & $-88,693$ \\
\hline Total & & $-5,952,590$ \\
\hline
\end{tabular}




\section{Discussion and Conclusion}

By analyzing the two appraisers' shapefiles from 2001 to 2011, Redland had an increase in housing units of $28 \%$. If we can then use this to assume that the population increased by approximately the same amount, then it is interesting to note that a $28 \%$ increase in population resulted in a water demand decrease of nearly $12 \%$ during the same time period. Given the finite amount of land that any particular area contains, a forecast that Miami-Dade County will grow from its current 2.5 million people to 3.2 million people by 2040 (Florida Housing Data Clearinghouse) means more land, much of it agricultural, would have to be converted. Coincidentally, this forecast is also a $28 \%$ increase from current population levels. Since farmland in the West that was acquired by public agencies contributed to so much water decrease, it is important to note that when those lands are removed from the analysis, water demand in the remaining area is seen to increase by 1.55 million GPD. Again, however, this increase is not due to development in the East, but to the conversion of row and field croplands and orchards to nurseries.

Though the MDC WASD does forecast an increase in water use for MDC, that is only within its boundaries. Its district will likely expand over time with a corresponding increase in the UDB and this will inevitably displace farmland. Though GPD per capita within the WASD has declined over time, from 158 to 134 gallons per capita per day from 2008 to 2013 (Miami-Dade County, Miami-Dade Green), the sheer volume of population growth expected is still forecast to increase total GPD within its district by over 20\% from 2011 to 2026 (MDC, 2011).

When this research was originally conceived, I planned to use actual metered water data to model water demand in the agricultural areas of Redland. However, when 
the data was provided by SFWMD, it became apparent that very few parcels contained actual pumpage data. In all of MDC, there are only 10 permits that had any data regarding actual pumpage. These 10 permits each consist of multiple non-contiguous parcels spread across MDC. Each permit has monthly pumpage records ranging from one record to 946 monthly records. Also, most of the parcels constituting these permits actually lie outside of Redland. This is because Redland lies within the "South Dade County Water Use Basin.” (Donna Rickabus, personal communication). Within this Basin, only pumpages exceeding 15 million gallons per month are recorded. This happened few times within Redland, and, again, each record is spread over the multiple non-contiguous parcels. For this reason, validating the ET estimations of water use with actual pumpage rates is nearly impossible. However, there is permit data that reflects water allocation for that permit. Though this does not offer the exact amount used it does offer the maximum amount that the lands comprising the permit are allowed to use. However, the District made clear that even this data was a "data dump" and that it not only contained numerous gaps but that many zero and blank values were subject to interpretation and that there was no standardization of the values (i.e., some permits with zero values were actually allocated GPD over 500,000 - Donna Rickabus, personal communication).

Despite the problems with this data, I compared it with the ET estimations by finding the difference in GPD per acre with the permitted allowable values. I only took those values of those parcels that lined up on top of each other and were therefore the same parcels. There were 92 parcels that met those conditions. For the permitted data, I took the allowable GPD per day and divided over what the records indicated as acres 
served. It should be noted, however, that this comparison contains possible geographic imprecision because the acres served is often larger than the parcel indicated on the map when the geometry is calculated in GIS. Thus the spatial data is used to align the two datasets while the field within the permitted data specifying acres served is used to calculate the GPD per acre. I then compared this with the GPD per acre of the average percent irrigated area for that same parcel using the ET method. For all agricultural parcels, ET averaged 1785 GPD per acre over those parcels while permitted allowable amounts averaged 2305 GPD per acre. By examining allowable water uses vs. ET per the three main agricultural categories a more specific picture emerges (Table 10). The results indicate that the ET method may be the most accurate for Groves and the least accurate when accounting for nurseries. However, again, it must be emphasized that the permitted data, even if it is perfectly accurate geographically, indicates only maximum allowable GPD per acre, not the actual average amount that was pumped. Nevertheless, since the disparities are large in the Row and Field as well as Nurseries categories it is possible that the ET method is actually underestimating water demand in Redland. However, these possible underestimations, far from undermining the conclusions of this research may actually bolster at least some of them. First, if agricultural water demand has been underestimated using ET, than the overall decrease in water demand estimated in this research may be even greater, thus lending even greater weight to the need to move away from population numbers as the most important factor in water demand. Second, the conversion of agricultural lands to residential lands may have led to an even more dramatic reduction in water demand in all such lands converted than this research suggests. Third, the identified areas of greatest water demand increase (those row and 
field croplands as well as groves that converted to nurseries) may possibly have been even more dramatic as well. Table 10 indicates little difference between ET estimates of GPD per acre (over actual irrigated land) between groves and nurseries with nurseries estimated to demand 50\% more water than row and field cropland. The permitted data, on the other hand, shows nurseries as demanding $104 \%$ more water than groves and $116 \%$ more water than row and field cropland. Therefore, if these numbers are more accurate, and the ET method underestimate disparities in the different type of croplands, then conversion of row and field croplands as well as groves to nurseries would result in an even greater increase in GPD per acre in all such lands converted. Due to the geographical and temporal intermittence of permitted data throughout Redland, a total comparative analysis between the two methods (and the different overall water demand estimates) is not tenable. Nevertheless, if ET does indeed underestimate water demand per acre for nurseries then their proliferation in Redland begs even closer scrutiny for water managers than this research suggests.

Table 10 Comparison of ET with allowable maximum GPD based on SFWMD permits

\begin{tabular}{|l|r|r|r|}
\hline Ag Land Use & Avg Permitted Allocated GPD & Avg Estimated GPD using ET & Percent diff \\
\hline Groves & 2260 & 2001 & $89 \%$ \\
\hline Row and Field & 2398 & 1341 & $56 \%$ \\
\hline Nurseries & 4895 & 2016 & $41 \%$ \\
\hline Nurseries/Groves & $217 \%$ & $101 \%$ & $46 \%$ \\
\hline Nurseries/Row and Field & $204 \%$ & $150 \%$ & $74 \%$ \\
\hline
\end{tabular}

A return to the hypotheses in Chapter 1 is now prudent to review how the results shed light on their accuracy.

I. The conversion of agricultural lands to residential lands in Redland has resulted in an overall increase in water demand for Redland. 
Result: The results clearly indicate that, in general, the opposite is true and that the conversion of agricultural land to residential lands has decreased water demand.

II. Farmland that converts to residential lands results in an increase in water demand per acre.

Result: This is also not true. The overall conversion from agricultural to residential resulted in decreases in water demand per acre.

III. Areas of greatest water demand intensity change are in the Northeast corner (Richmond West) and the Southeast Corner (Naranja) due to the heavy conversion from farmland to residential development there.

Result: Though there are certain sections of Richmond West and Naranja that have increased in water demand, most of these areas have actually decreased water demand due to lowered estimates of residential water use by WASD as well as conversion of agricultural lands to residential lands. Much of the greatest increase actually involved the conversion of row crops and groves to nurseries.

IV. With increases in development, water demand has shifted from West to East within Redland.

Result: Water demand has shifted to the East but this has more to do with the loss of croplands in the West then the conversion of farmland in the East.

V. Residential water use has increased while agricultural water use has decreased. Result: Though this is true in absolute numbers, with the total GPD for residential increasing and the total GPD for agriculture decreasing over the 10 
year period, as a percentage of overall demand, a slightly different picture emerges. Though Residential water demand increased both in absolute numbers as well as a percentage of overall water demand, the agricultural sector also increased its share of water demand, by going form $79 \%$ of overall demand to $82 \%$, despite the loss in overall GPD in the sector.

Though updated estimations of water demand by land use, as well as consistency in land categorization, would help make this exercise more accurate, the estimation techniques offered here do help to paint a picture of how water demand may actually be changing in Redland. With no question, large changes in land use have taken place and they surely have implications for water demand. Though the figures proffered here must only be used with caveats, the maps, particularly Figure 7, offer a picture that probably reflects best general water demand changes on the landscape, if not the exact quantity of change. Without reliable metered data, and with privacy concerns related to municipal water records of private citizens, it is difficult to portray water use with perfect, or even admirable, accuracy. Nevertheless, the effort is worthwhile. Since climate change brings with it continued sea level rise and future saltwater intrusion into groundwater and MDC continues to grow in population, it is prudent to perform an exercise that couples land use with water use as it may become a diminishing resource. By examining how past land use change may impact corresponding water use change planners and water managers, both in SFWMD and WASD, can better plan for the future.

Though much is often made of the increase in population that is sure to come with MDC's future, of even greater importance is accurately forecasting and planning for future land use changes. Though the two are related, they are not the same. Will 
newcomers live in single family homes or apartments? Will they start their own businesses, perhaps by adding to demand for more commercial space? Which farms will be developed to make room for further expansion? Will political will slow further farmland conversion? Will the Urban Development Boundary continue to expand? Will more farmland be acquired by the SFWMD? The answers to all of these questions have water demand implications. By using and refining the techniques this thesis calls upon, projections of land use change can be associated with water demand change and a more sustainable future can be both planned for and hopefully realized. 


\section{References}

Aillery, M., Shoemaker, R., \& Caswell, M. (2001). Agriculture and ecosystem restoration in South Florida: assessing trade-offs from water-retention development in the

Everglades agricultural area. American journal of agricultural economics, 83(1), 183-195.

Arsenault, R. (1984). The end of the long hot summer: the air conditioner and southern culture. The Journal of Southern History, 50(4), 597-628.

Balerdi, C. (2008). Dade Agriculture, Tropical Fruits, Dade County Farm Bureau UF/IFAS. http://www.dade-agriculture.org/dade-ag.htm

Baum, Melissa C., Dukes, Michael D., Miller, Grady L. (2002). Residential Irrigation Uniformity and Efficiency in Florida. Presentation, ASAE Annual International Meeting.

Billings, R. B., and Jones, C.V. (2008). Forecasting urban water demand. American Water Works Association.

Blanco, R. I., Melodie Naja, G., Rivero, R. G., \& Price, R. M. (2013). Spatial and temporal changes in groundwater salinity in South Florida. Applied Geochemistry, 38, $48-58$.

Brian, K. (2002). Water Resources: Health, Environment and Development-page 49. Retrieved from http://books.google.com

Chimney, M. J., \& Goforth, G. (2001). Environmental impacts to the Everglades ecosystem: A historical perspective and restoration strategies. Water Science \& Technology, 44(11), 93-100.

Degner, R. (2000). Economic impact of agriculture and agribusiness in Miami-Dade County, Florida (Doctoral dissertation, University of Florida).

Dzurik, A. A. A. (1984). Water use and public policy in Florida. Journal of Water Resources Planning and Management, 110(2), 167-179.

Foley, J. A., DeFries, R., Asner, G. P., Barford, C., Bonan, G., Carpenter, S. R., ... \& Snyder, P. K. (2005). Global consequences of land use. science,309(5734), 570-574.

Garofalo, Joe. (2008). Dade Agriculture, Horticulture, Dade County Farm Bureau UF/IFAShttp://www.dade-agriculture.org/dade-ag.htm

Gleick, P. H. (2003). Water use. Annual review of environment and resources, 28(1), 275-314. 
Huo, J., Mittl, A., Reilly, G., \& Sosnowski, R. (2006). Application of GIS to Plan LongRange Water Supply Facilities by Linking Land Use and Water Billing Data of City of Cape Coral in Southwest Florida. Proceedings of the Water Environment Federation, 2006(12), 1319-1327.

Lamberts, Mary and Olczyk, Teresa, (2008). Dade Agriculture, Vegetable Row Crops, Dade County Farm Bureau UF/IFAS http:/www.dade-agriculture.org/dade-ag.htm

Loffredo, Emily. (2008). Irrigation Water Requirement for a South Miami-Dade County Land Sample. Florida International University Independent Study Research Project.

Marella, R.L. (1999) Water withdrawals, use, discharge, and trends in Florida, 1995: U.S. Geological Survey Scientific Investigations Report 99-4002.

McCormick, P. V., Newman, S., \& Vilchek, L. W. (2009). Landscape responses to wetland eutrophication: loss of slough habitat in the Florida Everglades, USA.Hydrobiologia, 621(1), 105-114.

McPherson, B. F., \& Halley, R. B. (1996). The South Florida environment: a region under stress (Vol. 1134). United States Govt Printing Office.

Miami-Dade County GIS land use shapefiles (1994 and 2007).

Miami-Dade County, (2010). Water Conservation: The Miami-Dade Water Use Efficiency plan. http://www.miamidade.gov/waterconservation/library/reports/2011water-conservation-plan.pdf

Miami-Dade County Water Conservation (2008).

www.miamidade.gov/conservation/home.asp

Nerlove, M., and Sadka, E. (1991). Von Thunen's model of the dual economy. J Econ. $54,97-123$.

Ogburn, R. H. (2010). Urban Land Institute-2010 South Florida Economic and Development Outlook, available at http://www.agtectreasurecoast.com/pdf/uli_sfrpc.pdf

The Pacific Institute. (2013). Need to Know: Water Rate Series: Demand Forecasting.

Perry, W. B. (2008). Everglades's restoration and water quality challenges in south Florida. Ecotoxicology, 17(7), 569-578.

Purdum ED (2002). Florida waters: a water resources manual from Florida's water management districts. Southwest Florida Water Management District, Brooksville, available at http://www.swfwmd.state.fl.us/publications/files/floridawaters.pdf 
Renken, R.A., Dixon, Joann, Koehmstedt, John, Lietz, A.C., and others. (2005) Impact of Anthropogenic Development on Coastal Ground-Water Hydrology in Southeastern Florida, 1900-2000: Reston, Va., U.S. Geological Survey Circular 1275. http://sofia.usgs.gov/publications/circular/1275/index.html

Robert H. Freilich \& Linda Kirts Davis (1981). Saving the Land: The Utilization of Modern Techniques of Growth Management to Preserve Rural and Agricultural America, 13URB. LAW. 27, 29.

Shiklomanov, I. A., \& Rodda, J. C. (2004). Book review-//World Water Resources at the Beginning of the Twenty-First Century. Hydrological Sciences Journal-Journal des Sciences Hydrologiques, 49(2), 350-350.

Smajstrla, A.G, Boman, B.J., Haman, D.Z., Izuno, F.T., Pitts, D.J., Zazueta, F.S, 2008, Basic Irrigation Scheduling in Florida, University of Florida IFAS Extension.

Solecki, W. D. (2001). South Florida: The Reality of Change and the Prospects for Sustainability: The role of global-to-local linkages in land use/land covers change in south florida. Ecological Economics, 37(3), 339-356. doi: 10.1016/S09218009(01)00177-X.

Solecki, W. D., Long, J., Harwell, C. C., Myers, V., Zubrow, E., Ankersen, T., ... \& Snyder, G. (1999). Human-environment interactions in South Florida's Everglades region: Systems of ecological degradation and restoration. Urban Ecosystems, 3(3-4), 305-343.

Snyder, G. H., and Davidson, J. M. (1994). Everglades agriculture: Past, present, and future. In Everglades: The Ecosystem and Its Restoration (S. M. Davis and J. C. Ogden, eds), pp. 85-115. St. Lucie Press, Delray Beach, FL.

Turner, B. L., Meyer, W. B., \& Skole, D. L. (1994). Global land-use/land-cover change: towards an integrated study. AMBIO-STOCKHOLM-, 23, 91-91.

USDA, National Agricultural Statistics Service (2004). 2007 Census of Agriculture, Florida State and County Data, Volume 1, Geographic Area Series.

Walker, R. (2001). Urban sprawl and natural areas encroachment: Linking land covers change and economic development in the florida everglades. Ecological Economics, 37(3), 357.

Walker, Robert R. T. (1997)."Land use Dynamics and Ecological Transition: The Case of South Florida." Urban ecosystems 1.1: 37-47. Print. 
UNEPA (2001). "Our Built and Natural Environments", A Technical Review of the interactions between Land use, Transportation, and Environmental Quality.

http://www.epa.gov/dced/pdf/built.pdf

US Census Bureau (2010). Census Bureau State and County Quick Facts, available at http://quickfacts.census.gov/qfd/states/12/12086.html.

US Geological Survey (2008) Water-Use Facts for 2005 and Trends.

http://fl.water.usgs.gov/infodata/wateruse.html

Viessman Jr, W. (1990). Water management: Challenge and opportunity. Journal of Water Resources Planning and Management, 116(2), 155-169. 


\section{Appendices}

\section{Appendix 1}

Miami-Dade County WASD Estimations of Water Use by land use category. Note: old values are struck through and used for 2001 estimations while the other values are used for 2011 estimations. 


\section{MEMORANDUM}

Agenda Item No. 7 (I)

TO:

Honorable Chairman Joe A. Martinez and Members, Board of County Commissioners

FROM: R. A. Cuevas, Jr. County Attorney
DATE: July 7,2011

SUBJECT: Ordinance amending Sec. 24-43.1 of the Code, relating to sewage flows for sanitary sewers and the maximum allowable septic tank sewage loading requirements

This item differs from the original version as stated on the County Manager's memorandum.

The accompanying ordinance was prepared by Department of Environmental Resources Management and placed on the agenda at the request of Prime Sponsor Vice Chairwoman Audrey M. Edmonson.

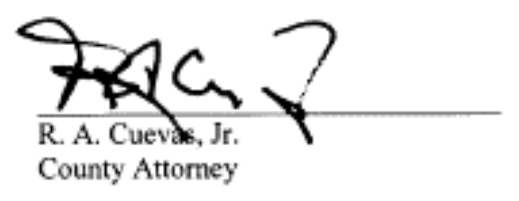

RAC/jls 


\section{Memorandum MaAmpaDe}

Date: July 7, 2011

Honorable Chaiman Joe A. Martinez

To: $\quad$ and Members, Board of County Commissioner

From:

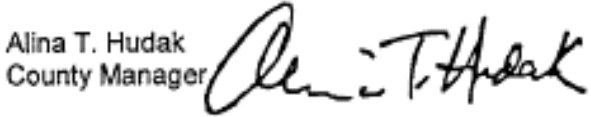

Subject: Ordinance Amending Section 24-43.1 of the Code of Miami-Dade County, Florida, Relating to Sewage Flows for Sanitary Sewers and the Maximum Allowable Septic Tank Sewage Loading Requirements

This substitute differs from the original ordinance in that (1) "Shopping Center/Mall: Shell/Common Area" was corrected from " $5 \mathrm{gpd} / 100 \mathrm{sq}$. $\mathrm{ft}$." to " $10 \mathrm{gpd} / 100 \mathrm{sq}$. $\mathrm{ft}$." (2) the heading "Industrial Land Uses" was removed and all items under this heading were merged with items under the heading "Commercial Land Uses" and alphabetized (3) additional explanation is provided regarding flow rate changes and (4) examples of changes and associated fees are provided.

Recommendation

It is recommended that the Board of County Commissioners approve the attached Ordinance Amending Section 24-43.1 of the Code of Miami-Dade County, Florida (Code), relating to sewage flows for sanitary

sewers and the maximum allowable septic tank sewage loading requirements.

\section{Scope}

The proposed ordinance involves environmental regulation throughout Miami-Dade County.

\section{Fiscal Impact/Funding Source}

This ordinance will not require additional funding and will be revenue neutral to the Department of Environmental Resources Management (DERM). DERM does not collect any fees for water and sewer connections.

The Miami-Dade Water and Sewer Department (WASD) charges for water and sewer connections based on a cost per gallon reflecting the value of water/sewer collection, treatment and transmission systems serving the property multiplied by the number of gallons assigned to the proposed use. The proposed ordinance, as compared to the flow rates in the Code, decreases the standard gallonage for various usages without changing the cost per gallon, thus reducing most sewer and water connection charges. WASD's approved FY2010-11 capital improvement plan/budget anticipated the slight reduction in water and sewer connection charges.

\section{Track Record/Monitor}

WASD charges and monitors the connection fees affected by this ordinance.

\section{Background}

Over 30 years ago, Section 24-43.1 of the Code set forth sewage unit flow rates to determine sewage flows for sanitary sewers and septic tank sewage loading for various land uses. DERM and WASD recently coordinated on proposing revised sewage unit flow rates for various land uses as set forth in Section 24-43.1 of the Code.

This proposed ordinance is being submitted for enactment in response to changes in the Florida Building Code which mandate the use of water-conserving fixtures in new construction and to better reflect overall water demand. WASD contracted with two local consulting firms, Cordova Rodriguez and Associates, Inc. and Samabi Group, Inc., to analyze the water usage in WASD's service area and provide

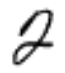


Honorable Joe A. Martinez, Chairman and Members, Board of County Commissioners

Page 2

recommendations for revising the sewage unit flow rates. The study found decreased water consumption in many of the land use categories. Therefore, the study concluded that it was necessary to revise the daily average sewage unit flow rates set forth in Chapter 24 based upon decreased water consumption in some land use categories throughout WASD's service area.

The study analyzed the five (5) residential land use categories and the 51 commercial/industrial land use categories. As a result of the study, the standard flow rates for all five (5) residential land use categories were decreased. The study also affected the standard flow rates for the 51 commercial/industrial land use categories as follows: ten (10) were decreased, nine (9) were increased, eleven (11) were modified and simplified in methodology to calculate the flow rate based on square footage of the business as opposed to variables that could change (i.e. number of students, number of doctors, etc), thirteen (13) remained the same and eight (8) were deleted because of the simplified methodology. In addition, two (2) new residential land use categories were added to allow for different home sizes and eleven (11) commercial land use categories were added to allow for variations of similar businesses. Therefore, the ordinance now includes seven (7) residential land use categories and 54 commercial land use categories for a total of 61 land use categories. In the proposed ordinance, the "Industrial Land Uses" heading was removed and those uses listed under that heading now appear under the "Commercial Land Uses" heading.

This ordinance also provides for the use of an engineering flow study, in lieu of the revised table of sewage unit flow rates for sanitary sewers and septic tank sewage loading, when requested by an applicant for special circumstances or to allow for non-standard fixtures (high efficiency, low flow, etc). Such studies would use recognized, standard practices of the engineering profession.

In some cases, this ordinance's sewage flow rates equate to decreased WASD connection charges as compared to the rates in the Code. The total overall sewage flow rate of a proposed business is determined by calculating the sewage flow rate the new business will generate minus the sewage fiow rate the previous business generated. The comparison of overall sewage flow rates and WASD connection charges of a proposed business is illustrated below:

Example 1: Proposed 3,900 sq. $f$. full service restaurant with 150 seats to replace a 3,900 sq, ft retail store.

Sewage Unit Flow Rates in Ch. 24-43.1(5) of the Code

Sewage Unit Flow Rates in Ch. 24-43.1(5) of the Code
\begin{tabular}{|c|c|c|c|c|c|}
\hline $\begin{array}{c}\text { Proposed } \\
\text { Business }\end{array}$ & $\begin{array}{c}\text { Sewage Unit Flow } \\
\text { Rate }\end{array}$ & $\begin{array}{c}\text { Total Sewage } \\
\text { Flow Rate }\end{array}$ & $\begin{array}{c}\text { Previous } \\
\text { Business }\end{array}$ & $\begin{array}{c}\text { Previous Sewage } \\
\text { Unit Flow Rate }\end{array}$ & $\begin{array}{c}\text { Overall Sewage } \\
\text { Flow Rate }\end{array}$ \\
\hline $\begin{array}{c}150 \text { seats } \\
\text { restaurant }\end{array}$ & $\begin{array}{c}50 \text { gallons per day } \\
\text { (gpd)/seat }\end{array}$ & $7,500 \mathrm{gpd}$ & $\begin{array}{c}3,900 \mathrm{sq} . \mathrm{ft} \\
\text { retail }\end{array}$ & $5 \mathrm{gpd} / 100 \mathrm{sq} . \mathrm{ft}$. & $7,305 \mathrm{gpd}$ \\
\hline
\end{tabular}

Sewage Flow Rates as reflected in this ordinance

\begin{tabular}{|c|c|c|c|c|c|}
\hline $\begin{array}{c}\text { Proposed } \\
\text { Business }\end{array}$ & $\begin{array}{c}\text { Sewage Unit Flow } \\
\text { Rate }\end{array}$ & $\begin{array}{c}\text { Total Sewage } \\
\text { Flow Rate }\end{array}$ & $\begin{array}{c}\text { Previous } \\
\text { Business }\end{array}$ & $\begin{array}{c}\text { Previous Sewage } \\
\text { Unit Flow Rate }\end{array}$ & $\begin{array}{c}\text { Overall Sewage } \\
\text { Flow Rate }\end{array}$ \\
\hline $3,900 \mathrm{sq} . \mathrm{ft}$. & $100 \mathrm{gpd} / 100 \mathrm{sq} . \mathrm{ft}$ & $3,900 \mathrm{gpd}$ & $\begin{array}{c}3,900 \mathrm{sq} . \mathrm{ft} . \\
\text { retall }\end{array}$ & $10 \mathrm{gpd} / 100 \mathrm{sq} . \mathrm{ft}$ & $3,510 \mathrm{gpd}$ \\
\hline
\end{tabular}


Honorable Joe A. Martinez, Chairman and Members, Board of County Commissioners

Page 3

In this case, this ordinance's unit sewage flow rate equals a reduced WASD connection charge, as compared to the rates in the Code, as illustrated below.

WASD Connection Charges based on Ch. 24-43.1(5) of the Code

\begin{tabular}{|c|c|c|c|}
\hline $\begin{array}{c}\text { WASD Connection } \\
\text { Charges }\end{array}$ & $\begin{array}{c}\text { WASD Unit Rate per } \\
\text { Gallons per Day (GPD) }\end{array}$ & $\begin{array}{c}\text { Overall Sewage Flow } \\
\text { Rate }\end{array}$ & Total Connection Charge \\
\hline Water & $1.39^{*}$ & $7,305 \mathrm{gpd}$ & $\$ 10,153.95$ \\
\hline Sewer & $5.60^{*}$ & $7,305 \mathrm{gpd}$ & $\$ 40,908.00$ \\
\hline Total & & & $\$ 51,061.95$ \\
\hline
\end{tabular}

"Impiementing Order 04-110 "Schedule of Ratos, Fees and Charges for Miami-Dade Water and Sewer Department"

WASD Connection Charges as reflected in this ordinance

\begin{tabular}{|c|c|c|c|}
\hline $\begin{array}{c}\text { WASD Connection } \\
\text { Charges }\end{array}$ & $\begin{array}{c}\text { WASD Unit Rate per } \\
\text { Gallons per Day (GPD) }\end{array}$ & $\begin{array}{c}\text { Overall Sewage Flow } \\
\text { Rate }\end{array}$ & Total Connection Charge \\
\hline Water & $1.39^{*}$ & $3,510 \mathrm{gpd}$ & $\$ 4,878.90$ \\
\hline Sewer & $5.60^{*}$ & $3,510 \mathrm{gpd}$ & $\$ 19,656.00$ \\
\hline Total & & & $\$ 24,534.90$ \\
\hline
\end{tabular}

* Implementing Order 04-110 "Schedule of Rates, Fees and Charges for Miami-Dade Water and Sewer Department

Furthermore, based on this ordinance's sewage flow rates, DERM is able to approve more units or increased density on properties served or to be served by septic tanks while complying with sewage loading restrictions. Pursuant to Chapter 24 , maximum allowable sewage loading is 1,500 gallons per day (gpd)/acre for properties served by septic tank and public water.

Example 2: Proposed eight (8) unit apartment building on one (1) acre parcel to be served by a septic tank system.

Sewage Unit Flow Rates in Ch. 24-43.1(5) of the Code

\begin{tabular}{|c|c|c|c|c|}
\hline $\begin{array}{c}\text { Proposed } \\
\text { Development }\end{array}$ & $\begin{array}{c}\text { Sewage Unit } \\
\text { Flow Rate }\end{array}$ & $\begin{array}{c}\text { Total Sewage } \\
\text { Flow Rate }\end{array}$ & $\begin{array}{c}\text { Maximum Allowable } \\
\text { Sewage Loading }\end{array}$ & Can DERM Approve? \\
\hline $\begin{array}{c}8 \text { unit apartment } \\
\text { building }\end{array}$ & $200 \mathrm{gpd} / \mathrm{apt}$ & $1,600 \mathrm{gpd}$ & $1,500 \mathrm{gpd} /$ acre & No, exceeds sewage \\
loading
\end{tabular}




\section{MEMORANDUM}

(Revised)

TO: $\quad$ Honorable Chairman Joe A. Martinez

and Members, Board of County Commissioners

DATE: July 7, 2011

FROM: R. A. Cuevas, Jr. County Attorne

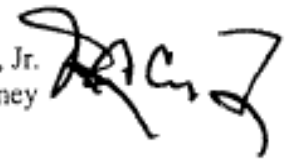

SUBJECT: Agenda Item No. 7(I)

Please note any items checked.

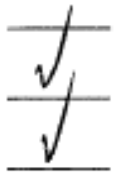

"3-Day Rule" for committees applicable if raised

6 weeks required between first reading and public hearing

4 weeks notification to municipal officials required prior to public hearing

Decreases revenues or increases expenditures without balancing budget

Budget required

Statement of fiscal impact required

Ordinance creating a new board requires detailed County Manager's report for public hearing

No committee review

Applicable legislation requires more than a majority vote (i.e., $2 / 3$ 's 3/5's , unanimous ) to approve

Current information regarding funding source, index code and available balance, and available capacity (if debt is contemplated) required 


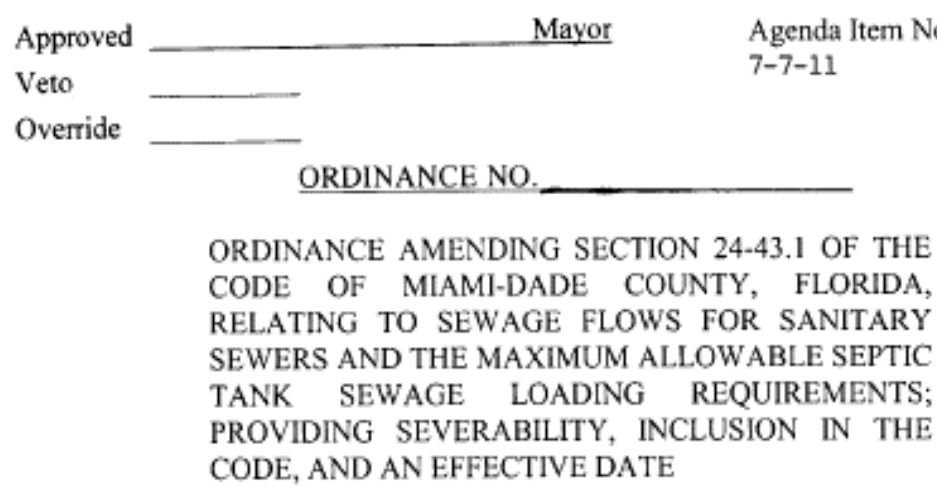

BE IT ORDAINED BY THE BOARD OF COUNTY COMMISSIONERS OF MIAMI-

\section{DADE COUNTY, FLORIDA:}

Section 1. Section 24-43.1 of the Code of Miami-Dade County, Florida, is hereby amended to read as follows:"

Sec. 24-43.1. Liquid waste disposal and potable water supply systems.

(1) The intent and purpose of this section is to safeguard the public health, safety, and welfare by regulating liquid waste storage, disposal and treatment methods other than sanitary sewers and any source of potable water supply.

(5) The following table shall be utilized by the Director or the Director's designee to determine sewage flows for sanitary sewers and the maximum allowable septic tank sewage loading requirements set forth in this chapter. If the Director or the Director's designee receives competent factual data and information such as actual on-site measured sewage flows or actual metered water bills, $>$ or an engineering flow study which utilizes recognized standard practices of the engineering profession, is signed and sealed by an engineer licensed by the State of Florida, and approved by the Director or the Director's designee, $\ll$ the Director or the Director's designee may utilize this data and information to determine sewage flows for sanitary sewers and the maximum allowable septic tank sewage loading requirements set forth in this chapter in lieu of the table below. This table shall not be utilized for the sizing of septic tanks. Sizing of septic tanks shall be in accordance with Florida Statutes regarding septic tanks.

[[Type of Land Use, Gathens Per Day (GPD)

Residential Land Uses:

Single-family residence: 350 (GPDiunit)

Townhouse residene: 250 (GPDitunit)

Apartment residence: 200 (GPDiunit)

1 Words stricken through and/or [[double bracketed]] shall be deleted. Words underscored and/or $\gg$ double arrowed $<<$ constitute the amendment proposed. Remaining provisions are now in effect and remain unchanged. 
Aobile home residence:-300 (GPD'tunit)

Duplex or twin heme residenee: 250 (GPD/unit)

Gommeretal Land Hses:

Barbershep: 10100(GPD/sq. At)

Beaty salen or hair-bettique: 75 (GPD)ehair)

Bowling alley: 100(GPD/lane)

Dentist's offiee:

(a) Per dentist: 250(GPD/dentist)

(b) Perwet chair: 200 (GPD/ehair)

Physieian's office: 250 (GPD/physieian)

Full-service restaufant (350 GPD minimum):50 (GPD/seat)

Bar or eecktail lounge: 15 (GPD/seat)

Fast foed resteturant ( $350 \mathrm{GPD}$ minimum): 35 (GPD/seat)

Take-out restaurant (350 GPD minimum); 501400 (GPD/sq. At.)

Hetel or-metel: 100 (GPD/roem)

Office building: $10 / 100$ (GPD/sq. ft.

Meter-vehiele service station: 10400(GPDisq. $\mathrm{ft}$ )

Shepping eenter (dry uses): 5/100 (GPDise. ft.)

Stadium, racetrack, ballpark: 3 (GPD/seat)

Stere witheut foed service: $5 / 100$ (GPDisg. $\mathrm{Al}$ )

Theater:

(a) Indeer auditerium: 3 (GPDiseat)

(b) Outdeer drive-in! 5 (GPDispaee)

Camper or trailer park: 150 (GPD'spaee)

Banquet halls: 25 (GPD/seat)

Garwash:

(a) Reeyeling-type: 750 (GPD/bay)

(b) Hand-type: 3,500 (GPD/bay)

Eoinlaundries: 225 (GPD/washef)

Country clubs: 25 (GPDimember)

Funeral hemes: 10400 (GPD/sq- $\mathrm{At}$ ) 
Gas station/mini-mart: 450 (GPDitunit)

Health spolgyms: 35/100 (GPD/se. ft.)

Veterinarian's office:

(a) Per veterinarian: 250 (GPD/vet)

(b) With kennels: 30 (GPD/eage)

Kennels: 30 (GPD fenge)

Marines: 40 (GPD'slip)

Feed preparation outlets (bakeries, meat markets, commissaries) (350 GPD minimum): 50 (GPDisq. $\mathrm{At}$ )

Petgreeming:

(a) Store-space: 10/100 (GPDisq. ft.)

(b) Per fub: 75 (GPDitub)

Industrial Land bses:

Fatery witheut shewers: 10400 (GPDise ft.)

Fueterywith chewers: 20/400 (GPD/se-ft)

Airpert: 5(GPD/passenger); 10 (GPD/employee)

House of worship: 3 (GPD/seat)

Hespital: 250(GPD/ped)

Convalescent or nursing heme: 150 (GPD)bed)

Park:

(a) With toilets enly: 5 (GPDipersen)

(b) With showers and toilets: 20 (GPD/persen)

Other residential-institution or faeility (ineluding adult-congregate-living units): 100 (GPD/persen)

Seheels.

(a) Day-eareinursery: 5(GPDistudent)

(b) Regular seheel: 10 (GPD/student)

(c) With of feterin add: 5 (GPD/student)

(d) With shewers add: 5 (GPDistudent)

(e) Teachers and staff: 15 (GPD/persen)

Publie swimming facility:-10(GPD/persem)

Warehouse/industrialspeculatien building: 204000 (GPDisq. ft.)

Sterage warehouse of mini-wareheuse: $5 / 1000(G P D / s q$. $\mathrm{At})$ ]] 


\section{Agenda Item No, $7(\mathrm{I})$}

Page 4

\section{$\gg$ Type of Land Use/Gallons per Day (GPD)}

\section{Residential Land Uses:}

Single Family Residence Less than 3001 sq.ft: 220 gpd/unit

$3001-5000$ sq.ff: 320 gpd/unit

More than 5000 sq.ft: 550 gpd/unit

Townhouse Residence 180 gpd/unit

Apartment 150 gpd/unit

Mobile Home Residence/Park 180 gpdrunit

Duplex or Twin Home Residence 180 gpd/unit

\section{Commercial Land Uses: $<<$}

$>$ Airport:

(a) Common Area/Concourse $5 \mathrm{gnd} / 100 \mathrm{sq}, \mathrm{ft}$.

(b) Retail 10 gnd/100sq.ft.

(c) Food Service See Restaurant use for allocation $<<^{2}$

$>$ Banquet Hall $15 \mathrm{gpd} / 100 \mathrm{sq} . \mathrm{ft}$.

With Kitchen $50 \mathrm{gpd} / 100 \mathrm{sq} . \mathrm{ft}$

Bar $<<[$ and $]]>$ or CocktailLLounge 20 gpd/100 sq.ft.

Barber Shop $15 \mathrm{gpd} / 100 \mathrm{sq} . \mathrm{ft}$.

Beauty Shop 25 gpd/100 sq.ft.

Bowling Alley 100 gpd/lane $\ll$

[[Friter-Touriat-Park

150.0] ]

$>$ Car Wash:
(a) Manual Washing 350 gnd/bay
(b) Automated Washing 5500 gpd/bay
With recycle system
Based on system design and evaluation by the Department

\begin{tabular}{lc} 
Coin Laundry & $145 \mathrm{gpd} / \mathrm{washer}$ \\
Country Club & $15 \mathrm{gpd} / 100 \mathrm{sq} . \mathrm{ft}$. \\
\hline $\begin{array}{l}\text { With Kitchen } \\
\text { Dentist's Office }\end{array}$ & $50 \mathrm{ggd} / 100 \mathrm{sq} . \mathrm{ft}$. \\
\hline
\end{tabular}

\footnotetext{
${ }^{2}$ The differences between the substitute and the original item are indicated as follows: words double stricken through and/or [[ shall be deleted, words double underlined and/or $>>$ double arrowsd $<<$ constitute the amendment proposed.
} 
Agenda Item No. 7 (I)

Page 5

Food Preparation Outlets (Bakeries, Meat

Markets, Commissaries, etc.) 35 gsd $/ 100$ sq.ft.

Funeral Home $10 \mathrm{gpd} / 100 \mathrm{sq} . \mathrm{ft} .<$

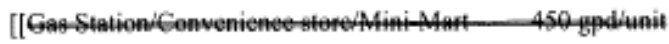

With-singlo-attem

$\gg$ Gas Station/Convenience store/Mini-Mart
(a) Without car wash 450 .gpd/unit
(b) With single automated car wash 1750 gpd/unit<e

$>$ Fitness Center or Gym $\quad 10$ gpd/100 sq.tt. $<<$

> Hospital 250 gpd/bed $<<$

$>$ Hotel or Motel 100 gpd/room $<<$

> House of Worship $10 \mathrm{gpd} / 100 \mathrm{sq}$.ft

Industrial:

(a) Warehouse/Spec. Bldg. Igpd/100 sq.fl.

(b)Self-servicestorage units $1.5 \mathrm{gpd} / 100 \mathrm{sq} . \mathrm{fl}$.

(c) Industrial-Wet $20 \mathrm{gpd} / 100 \mathrm{sq} . \mathrm{ft}$

(d)Industrial-Dry $2.5 \mathrm{gpd} / 100 \mathrm{sq} \mathrm{ft}<\mathrm{C}$

> Kennel $15 \mathrm{gpd} / \mathrm{cage}$

Marina $60 \mathrm{gpd} / \mathrm{slip}$

Motor Vehicle Service Station $10 \mathrm{gpd} / 100$ sq. $\mathrm{ft} .<<$

$>$ Nursing/Convalescent Home $150 \mathrm{knd} / \mathrm{bed}<$

$\gg$ Office Building 5 gpd/100 sq.fी $<<$

$\gg$ Other Residential Facility Institution:

(a) Congregate LivingFacility (CLF) $75 \mathrm{gpd} / \mathrm{bed}$

(b) Jail 150 spdiperson

(c) Other 100 gpdiperson $<<$

$>$ Pet Grooming $55 \mathrm{gpd} / 100 \mathrm{sq} . \mathrm{ft}$

Physician's Office $20 \mathrm{gpd} / 100$ sq.ft. $<<$

$>>$ Public Park:

(a) With toilets only 5 gpd/person

(b) With.toilets and showers 20 gpdiperson

Public Swimming Pool Facility 30 gpdiperson $<<$ 
Agenda Item No. 7(I)

Page 6

> Restaurant:

$\begin{array}{ll}\text { (a) Full Service } & 100 \mathrm{gpd} / 100 \mathrm{sq} . \mathrm{ft} \\ \text { (b) Fast Food } & 50 \mathrm{gpd} / 100 \mathrm{sq} . \mathrm{ft} . \\ \text { (c) Take Out } & 100 \mathrm{gnd} / 100 \mathrm{sq} . \mathrm{ft} . \\ & 10 \mathrm{gpd} / 100 \mathrm{sq} . \mathrm{ft} .<\end{array}$

$>$ School:

(a)Day Care/Nursery (adults and children) $20 \mathrm{gpd} / 00$ sq.ft.

(b)Regular school $\quad 12 \mathrm{gpd} / 100$ sq.ft $\ll$

>Shopping Center/Mall:

Shell/Common Area

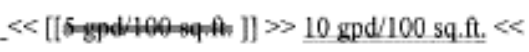

>Stadium, Ballpark, Racetrack,

Eronton, Auditorium, etc. 3 gpd/seat

Theater:

(a) Indoor $3 \mathrm{gpd} / \mathrm{seat}$

(b) Outdoor 5 gpd/space

(c) Drive-in 5 gnd/space $<<$

$>$ Trailer or Tourist Park $150 \mathrm{gpd} / \mathrm{space}^{2}<$

$>$ Veterinarian Office $20 \mathrm{gpd} / 100 \mathrm{sq} . \mathrm{ft} . \ll$

\section{I/ Iminstrial band- bsest}

Aimper:

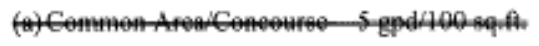

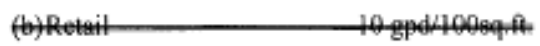

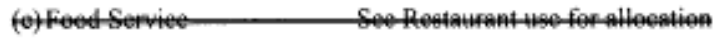
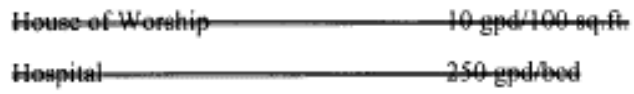

indentriat:

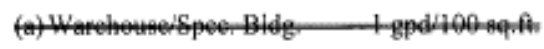

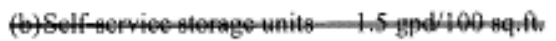

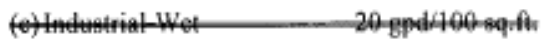

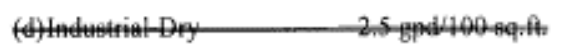

Hurungement Homo-150-gpdibed

Other-Regidential Facilityinstitutiom -

(a) Gengregate biving

Fineility (6LF) is gpdibed 

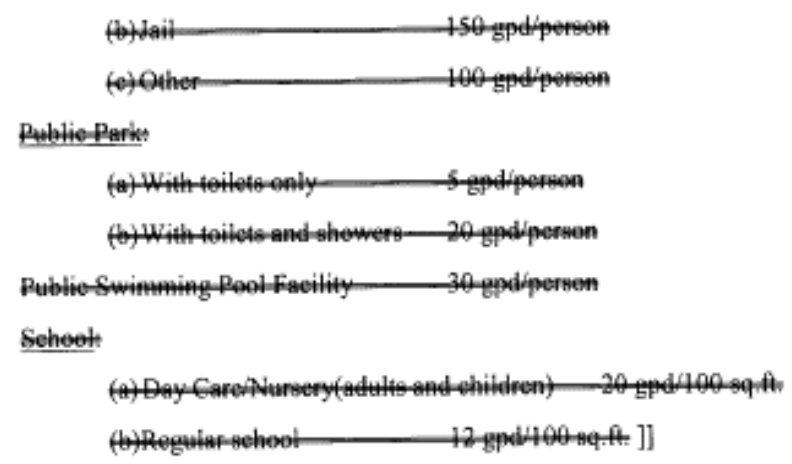

Section 3. If any section, subsection, sentence, clause or provision of this ordinance is held invalid, the remainder of this ordinance shall not be affected by such invalidity.

Section 4. It is the intention of the Board of County Commissioners, and it is hereby ordained that the provisions of this ordinance, including any sunset provision, shall become and be made a part of the Code of Miami-Dade County, Florida. The sections of this ordinance may be renumbered or relettered to accomplish such intention, and the word "ordinance" may be changed to "section," "article," or other appropriate word.

Section 5. This ordinance shall become effective ten (10) days after the date of enactment unless vetoed by the Mayor, and if vetoed, shall become effective only upon an override by this Board.

PASSED AND ADOPTED:

Approved by County Attomey as to form and legal sufficiency:

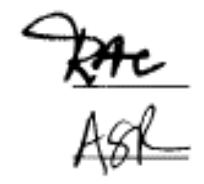

Prepared by:

Abbie Raurell Schwaderer

Prime Sponsor: $\quad$ Vice Chairwoman Audrey M. Edmonson 
Appendix 2: Miami-Dade County Land Use Codes used by the appraiser's office in conjunction with supplemental State Land Use Codes (Extracted from Loffredo, 2008 and originally obtained from Daena L. Harrell, CFE, Real Estate Evaluator II)(Attached as a PDF document) 
Appendix III: CLUC and SLUC Codes for Miami Dade County

Contact: Daena L. Harrell, CFE, Real Estate Evaluator II

\begin{tabular}{|c|c|c|c|}
\hline Cluc & Sluc & State Ex Code & Description \\
\hline 1 & 110 & $\underline{21}$ & PARAPLEGIC (MIIITARY \& QUADRIPLEGIC) / N/A \\
\hline 1 & 120 & $\underline{22}$ & PARAPLEGIC (CIVILIAN DISABIITY) / N/A \\
\hline 1 & 100 & & SINGLE FAMIIY / N/A \\
\hline 2 & 810 & & MUITIFAMILY - 2 LIVING UNITS:DUPLEX OR/N/A \\
\hline 3 & 300 & & MULTIFAMILY (10 UNITS OR MORE) / N/A \\
\hline 3 & 800 & & MULTIFAMILY - (3 TO 9 UNITS) / N/A \\
\hline 4 & 0 & & VACANT SINGLE FAMILY - TOTAL VALUE / N/A \\
\hline 4 & 400 & & (SINGLE FAMIILY)-TOTAL VALUE / N/A \\
\hline 5 & 0 & & VACANT CLUSTER SITES - TOTAL VALUE / N/A \\
\hline 5 & 420 & & CLUSTER - TOTAL VALUE / N/A \\
\hline 6 & 200 & & $\begin{array}{l}\text { MOBILE HOMES(SINGLE ON RESIDENTIAL } \\
\text { SITE) / N/A }\end{array}$ \\
\hline 7 & 0 & & VACANT CONDO SITES - TOTAL VALUE / N/A \\
\hline 7 & 430 & & CONDOMINIUM - TOTAL VALUE / N/A \\
\hline 8 & 500 & & $\begin{array}{l}\text { COOPERATIVES - RESIDENTIAL - TOTAL } \\
\text { VALUE / N/A }\end{array}$ \\
\hline 9 & 1200 & & $\begin{array}{l}\text { MIXED USE - PRIMARY USE RESIDENTIAL } \\
\text { WITH / N/A }\end{array}$ \\
\hline 10 & 0 & & VACANT TOWNHOUSE SITES - TOTAL VALUE / N/A \\
\hline 10 & 410 & & TOWNHOUSES - TOTAL VALUE / N/A \\
\hline 10 & 5000 & $\underline{72}$ & IMPROVED AGRICULTURAL HOMESITES / N/A \\
\hline 11 & 2200 & & RESTAURANTS, DRIVE-IN/DRIVE-THRU / N/A \\
\hline 11 & 2100 & & RESTAURANTS, CAFETERIAS (SEATING \& / N/A \\
\hline 11 & 4300 & & LUMBER YARDS / N/A \\
\hline 11 & 3000 & & FLORIST, RETAIL, GREENHOUSES / N/A \\
\hline 11 & 2620 & & GAS STATION \& MINI-MART ONLY / N/A \\
\hline 11 & 1100 & & STORES, ONE STORY / N/A \\
\hline 11 & 1600 & & SHOPPING CENTERS-/N/A \\
\hline 11 & 1410 & & CONVENIENCE STORE/CENTERS / N/A \\
\hline 11 & 1400 & & SUPERMARKET, GROCERY STORE / N/A \\
\hline 11 & 1300 & & DEPARTMENT STORE / N/A \\
\hline 11 & 2610 & & SERVICE STATION \& MINI MART/ / N/A \\
\hline 11 & 1610 & & SHOPPING CENTERS - / N/A \\
\hline 12 & 2500 & & CONSUMERS SERVICE: / N/A \\
\hline 12 & 7610 & & MORTUARIES, FUNERAL HOMES / N/A \\
\hline
\end{tabular}

-64 - 


\begin{tabular}{|l|l|l|l|}
\hline Cluc & Sluc & State Ex Code & \\
\hline & & & \\
\hline 13 & 1910 & & PROFESSIONAL SERVICES BUILDINGS / N/A \\
\hline 13 & 2400 & & INSURANCE COMPANY OFFICE BUILDING / N/A \\
\hline 13 & 1930 & & MEDICAL OFFICE BUILDINGS / N/A \\
\hline 13 & 1800 & & OFFICE BUILDINGS - NON-PROFESSIONAL / N/A \\
\hline 13 & 1700 & & OFFICE BUILDINGS - NON-PROFESSIONAL / N/A \\
\hline & & & $\begin{array}{l}\text { MOBIE OR PRE-FAB TEMP.RESIDENTIAL } \\
\text { SALES / N/A }\end{array}$ \\
\hline 13 & 710 & & PROFESSIONAL SERVICES BUILDINGS / N/A \\
\hline 13 & 1900 & & FINANCIAL INSTITUTIONS (BANKS, / N/A \\
\hline 13 & 2300 & & WHOLESALE OUTLETS, PRODUCE / N/A \\
\hline 14 & 2900 & & ENCLOSED THEATERS, ENCLOSED / N/A \\
\hline 15 & 3200 & & RACE TRACKS; HORSE, AUTO OR DOG / N/A \\
\hline 15 & 3700 & & TOURISTS ATTRACTIONS,PERMANENT / N/A \\
\hline 15 & 3500 & & NIGHTCLUBS, COCKTAIL LOUNGES,BARS. / N/A \\
\hline 15 & 3300 & & DRIVE-IN THEATERS, OPEN STADIUM / N/A \\
\hline 15 & 3100 & & BOWLING ALLEYS, SKATING RINS, POOL / N/A \\
\hline 15 & 3400 & & LEASEHOLD INTERESTS (GOVERNMENT / N/A \\
\hline 16 & 9000 & & SHOPPING CENTERS - REGIONAL / N/A \\
\hline 17 & 1520 & & HOMES FOR THE AGED - TOTAL VALUE / N/A \\
\hline 17 & 7400 & & D1 \\
\hline 17 & 2010 & & DOCKS - TOTAL VALUE / N/A \\
\hline 17 & 1500 & & SHOPPING CENTERS-SUPER-REGIONAL / N/A \\
\hline 17 & 450 & & INTERVAL OWNERSHP - TOTAL VALUE / N/A \\
\hline 17 & 1510 & & SHOPPING CENTER - DECLARATION OF \\
\hline 18 & 1110 & & CONDO. / N/A \\
\hline 18 & 1810 & & OFFICES - CONDO / N/A \\
\hline 18 & 1920 & & PROFESSIONAL OFFICES - CONDO / N/A \\
\hline 18 & 2310 & & FINANCIAL INSTITUTIONS (CONDO) / N/A \\
\hline 18 & 4110 & & $\begin{array}{l}\text { CONDO WAREHOUSE-LIGHT } \\
\text { MANUFACTURNG / N/A }\end{array}$ \\
\hline 18 & 4810 & & CONDO WAREHOUSE-TERMINAL OR STORAGE / N/A \\
\hline 19 & 2700 & & AUTO SALES, AUTO REPAIR AND / N/A \\
\hline 21 & 3900 & & HOTELS / N/A \\
\hline 22 & 3910 & & MOTELS / N/A \\
\hline 23 & 440 & & VACATION CONDO - MOTEL \& CONDOMINIUM / N/A \\
\hline
\end{tabular}

$-65$. 


\begin{tabular}{|c|c|c|c|}
\hline Cluc & Sluc & State Ex Code & Description \\
\hline 24 & 700 & & $\begin{array}{l}\text { MISCELLANEOUS RESIDENTIAL (MIGRANT } \\
\text { CAMPS, / N/A }\end{array}$ \\
\hline 24 & 701 & & ANCILLARY RESIDENTIAL USE BUILDINGS-EX: / N/A \\
\hline 25 & 0 & & HISTORIC PRESERVATION / N/A \\
\hline 25 & 41 & $\underline{55}$ & ENTERPRISE ZONE - TOTAL VALUE / N/A \\
\hline 26 & 2600 & & SERVICE STATIONS - AUTOMOTIVE(ONLY)/N/A \\
\hline 29 & 1210 & & $\begin{array}{l}\text { MIXED USE - PRIMARY USE COMMERCIAL } \\
\text { WITH / N/A }\end{array}$ \\
\hline 31 & 4700 & & MINERAL PROCESSING: PHOSPHATE / N/A \\
\hline 31 & 9200 & & MINING LANDS, (ROCKPITS) PETROLEUM, / N/A \\
\hline 32 & 4100 & & LIGHT MANUFACTURING PLANTS, / N/A \\
\hline 32 & 4600 & & $\begin{array}{l}\text { OTHER FOOD PROCESSING:CANDY } \\
\text { FACTORIES, / N/A }\end{array}$ \\
\hline 32 & 4400 & & PACKING PLANTS: FRUIT \& VEGETABLES / N/A \\
\hline 34 & 4500 & & CANNERIES: FRUIT \& VEGETABLE, / N/A \\
\hline 36 & 4200 & & HEAVY INDUSTRIAL: HEAVY EQUIPMENT / N/A \\
\hline 36 & 4310 & & SAWMILLS, PLANNING MILLS / N/A \\
\hline 37 & 4800 & & WAREHOUSE - DISTRIBUTION TERMINALS, / N/A \\
\hline 37 & 4900 & & OPEN STORAGE, NEW \& USED BUILDING / N/A \\
\hline 39 & 0 & & MIXED USED - INDUSTRIAL PRIMARY USE / N/A \\
\hline 40 & 8900 & 80 & MUNICIPAL OWNED - OTHER THEN PARKS, / N/A \\
\hline 40 & 3800 & & GOLF COURSES - MUNICIPAL / N/A \\
\hline 40 & 8200 & $\underline{80}$ & $\begin{array}{l}\text { MUNICIPAL - FOREST, PARKS, RECREATIONAL } \\
\text { AREAS / N/A }\end{array}$ \\
\hline 41 & 7200 & $\underline{30}$ & $\begin{array}{l}\text { EDUCATIONAL(PRIVATE SCHOOLS \& } \\
\text { COLLEGES) / N/A }\end{array}$ \\
\hline 41 & 7210 & 34 & DAY CARE SCHOOLS / N/A \\
\hline 42 & 7700 & $\underline{32}$ & CLUBS, LODGES, YACHT CLUBS,UNION HALIS. / N/A \\
\hline 43 & 600 & & RETIREMENT HOMES (NOT ELIGIBLE FOR / N/A \\
\hline 43 & 7300 & $\underline{40}$ & $\begin{array}{l}\text { PRIVATELY OWNED HOSPITALS, CLINICS, } \\
\text { VET'S / N/A }\end{array}$ \\
\hline 43 & 7410 & $\underline{\underline{41}}$ & HOMES FOR THE AGED - RETIREMENT / N/A \\
\hline 43 & 7500 & $\underline{34}$ & ORPHANAGES, ACLF, ASSISTED LIVING OR / N/A \\
\hline 43 & 7800 & & SANTTARIUMS, CONVALESCENT, REST HOMES, / N/A \\
\hline 43 & 8500 & $\underline{\underline{40}}$ & HOSPITALS / N/A \\
\hline
\end{tabular}

$-66-$ 


\begin{tabular}{|c|c|c|c|}
\hline Cluc & Sluc & State Ex Code & $\begin{array}{r}\text { Description } \\
\end{array}$ \\
\hline 44 & 7100 & 36 & CHURCHES - RELIGIOUS EXEMPTION / N/A \\
\hline 46 & 8600 & 85 & PENAL INSTITUTION - COUNTY OR / N/A \\
\hline 47 & 8210 & 85 & $\begin{array}{l}\text { COUNTY - FOREST, PARKS, RECREATIONAL } \\
\text { AREAS / N/A }\end{array}$ \\
\hline 47 & 8600 & $\underline{85}$ & $\begin{array}{l}\text { COUNTY OWNED-(OTHER THEN PUBLIC } \\
\text { SCHOOLS, / N/A }\end{array}$ \\
\hline 47 & 3810 & & GOLF COURSES - DADE COUNTY / N/A \\
\hline 48 & 8300 & $\underline{86}$ & PUBLIC COUNTY SCHOOLS-INCLUDE / N/A \\
\hline 50 & 7900 & 31 & CULTURAL ORGANIZATIONS, FACIITIES / N/A \\
\hline 51 & 9740 & & $\begin{array}{l}\text { PRIVATE PARK, REC.AREA, } \\
\text { RDS,GREENWAY,ETC./ N/A }\end{array}$ \\
\hline 51 & 9750 & & PRIVATE PARK / N/A \\
\hline 52 & 9760 & & PLAYGROUND (NON-GOVERNMENTAL) / N/A \\
\hline 53 & 3820 & & GOLF COURSES \& DRIVING RANGES - / N/A \\
\hline 54 & 7600 & 38 & CEMETERIES,CREMATORIUMS / N/A \\
\hline 56 & 7220 & $\underline{35}$ & SCIENTIFIC EXEMPTION / N/A \\
\hline 57 & 7110 & 37 & PARSONAGE EXEMPTION / N/A \\
\hline 58 & 7710 & 34 & YWCA \& YMCA EXEMPTION / N/A \\
\hline 59 & 0 & & MIXED USE - INSTITUTIONAL USES / N/A \\
\hline 60 & 0 & $\underline{63}$ & REFERENCE ONLY / N/A \\
\hline 61 & 2000 & & AIRPORTS (PRIVATE OR COMMERCIAL) / N/A \\
\hline 62 & 9800 & $\underline{62}$ & CENTRALLY ASSESSED - BY / N/A \\
\hline 63 & 9100 & & UTIITY, GAS \& ELECTRICITY, TELEPHONE / N/A \\
\hline 64 & 9400 & & RIGHT-OF-WAY, STREETS, ROADS / N/A \\
\hline 65 & 2800 & & PARKING LOTS (COMMERCIAL OR PATRON) / N/A \\
\hline 65 & 2810 & & $\begin{array}{l}\text { PARKING GARAGE (COMMERCIAL OR } \\
\text { PATRON)/N/A }\end{array}$ \\
\hline 65 & 2820 & & MOBILE HOME PARKS AND RV PARKS / N/A \\
\hline 66 & 4001 & & EXTRA FEATURES ON VACANT INDUSTRIAL - / N/A \\
\hline 66 & 9901 & & EXTRA FEATURES ON VACANT ACREAGE NOT / N/A \\
\hline 66 & 8001 & & $\begin{array}{l}\text { EXTRA FEATURES ON VACANT } \\
\text { GOVERNMENTAL / N/A }\end{array}$ \\
\hline 66 & 5001 & 72 & $\begin{array}{l}\text { EXTRA FEATURES ON VACANT AG. } \\
\text { CLASSIFIED / N/A }\end{array}$ \\
\hline 66 & 1001 & & EXTRA FEATURES ON VACANT COMMERCIAL / N/A \\
\hline
\end{tabular}

$-67$. 


\begin{tabular}{|c|c|c|l|}
\hline Cluc & Sluc & State Ex Code & \\
\hline 66 & 0 & & $\begin{array}{l}\text { EXTRA FEATURES ON VACANT } \\
\text { RESDENTIAL / EXCEPT PARKING }\end{array}$ \\
\hline 66 & 7001 & & $\begin{array}{l}\text { EXTRA FEATURES ON VACANT } \\
\text { INSTITUTIONAL / N/A }\end{array}$ \\
\hline 71 & 6688 & & PAPAYAS GROVES / N/A \\
\hline 71 & 6655 & & LIMES GROVES / N/A \\
\hline 71 & 6691 & & MISCELLANEOUS SUBTROPICAL OR / N/A \\
\hline 71 & 6690 & & MIXED SUBTROPICAL OR TROPICAL / N/A \\
\hline 71 & 6600 & $\underline{72}$ & ORCHARD GROVES, CITRUS ETC / N/A \\
\hline 71 & 6684 & & AVOCADOS GROVES / N/A \\
\hline 71 & 6686 & & MANGO GROVES / N/A \\
\hline 71 & 6687 & & SAPOTE GROVES / N/A \\
\hline 79 & 5010 & $\underline{72}$ & IMPROVED AGRICULTURAL BUILDING SITES / N/A \\
\hline 79 & 6810 & & LOTS, PENS, AND OPERATING / N/A \\
\hline 80 & 8710 & 90 & VACANT - STATE OWNED LANDS / N/A \\
\hline 80 & 8810 & 95 & VACANT - FEDERAL OWNED LANDS / N/A \\
\hline 80 & 8610 & $\underline{85}$ & VACANT - COUNTY OWNED LANDS / N/A \\
\hline 80 & 8310 & $\underline{86}$ & VACANT BPI LANDS / N/A \\
\hline 80 & 8910 & $\underline{80}$ & VACANT - MUNICIPAL OWNED LANDS / N/A \\
\hline 81 & 9720 & & LAND SUBJECT TO NATURAL FOREST \\
\hline 81 & 6760 & & COMMUNITY / N/A \\
\hline 81 & 6720 & $\underline{72}$ & PIGS, GOATS, SHEEP / N/A \\
\hline 81 & 6730 & & APIARY, BEE'S / N/A \\
\hline 81 & 6740 & & PISCICULTURE (TROPICAL FISH) / N/A \\
\hline 81 & 6716 & & MISCELLANEOUS FOWL (QUAIL, / N/A \\
\hline 81 & 6752 & & WORMS / N/A \\
\hline 81 & 6715 & & TURKEYS / N/A \\
\hline 81 & 6800 & & DAIRY FEED LOTS / N/A \\
\hline 81 & 6910 & $\underline{72}$ & $\begin{array}{l}\text { ORNAMENTALS-FIELD NURSERIES, (IN- } \\
\text { GROUND) / N/A }\end{array}$ \\
\hline 81 & 6915 & & TREE NURSERY ORNAMENTAL / N/A \\
\hline 81 & 7000 & & VACANT INSTITUTIONAL / N/A \\
\hline 81 & 9900 & & ACREAGE - NOT CLASSIFIED AGRICUITURAL / N/A \\
\hline 81 & 9902 & & NEW PLAT - VAC. ACREAGE (VALUE BASED / N/A \\
\hline 81 & 5311 & & DESIGNATED MARKET LOCATION, SOIL / N/A \\
\hline 81 & 6711 & & EGG PRODUCTION / N/A \\
\hline & & & \\
\hline
\end{tabular}

$-68-$ 


\begin{tabular}{|c|c|c|c|}
\hline Cluc & Sluc & State Ex Code & Description \\
\hline 81 & 6930 & & CONTAINER NURSERIES (ABOVE / N/A \\
\hline 81 & 5321 & & DESIGNATED MARKET LOCATION, SOIL / N/A \\
\hline 81 & 0 & & EXTRA FEATURES ON VACANT RESIDENTIAL / N/A \\
\hline 81 & 1000 & & VACANT COMMERCIAL / N/A \\
\hline 81 & 4000 & & VACANT INDUSTRIAL/ N/A \\
\hline 81 & 5310 & 72 & VEGETABLE CROPLANDS MIXED/ROTATED / N/A \\
\hline 81 & 5313 & & DESIGNATED MARKET LOCATION, SOIL / N/A \\
\hline 81 & 5312 & & DESIGNATED MARKET LOCATION, SOIL / N/A \\
\hline 81 & 6710 & & CHICKENS / N/A \\
\hline 81 & 5320 & & MIXED/ROTATED VEGETABLES MUCK SOIL / N/A \\
\hline 81 & 5322 & & DESIGNATED MARKET LOCATION, SOIL / N/A \\
\hline 81 & 5370 & & STRAWBERRIES / N/A \\
\hline 81 & 5390 & & MISCELLANEOUS OTHER CROPS / N/A \\
\hline 81 & 6100 & 72 & IMPROVED PASTURES / N/A \\
\hline 81 & 6200 & & SEMI-IMPROVED PASTURE / N/A \\
\hline 81 & 6300 & & NATIVE PASTURE - RANGE LAND / N/A \\
\hline 81 & 6700 & 72 & MISCELLANEOUS ANIMALS (NON GRAZING / N/A \\
\hline 81 & 5315 & 72 & LATIN AND ORIENTAL VEGETABLES / N/A \\
\hline 82 & 9600 & & SEWAGE DISPOSAL, DRAINAGE RESERVOIRS / N/A \\
\hline 83 & 9610 & & WASTE LANDS, MARSH, SWAMP LANDS / N/A \\
\hline 84 & 9700 & 73 & OUTDOOR RECREATIONAL OR PARK LAND OR / N/A \\
\hline 84 & 9710 & 74 & ENVIRONMENTALLY ENDANGERED LAND / N/A \\
\hline 85 & 9500 & 93 & $\begin{array}{l}\text { SOUTH FLORIDA WATER MANAGEMENT } \\
\text { DISTRICT / N/A }\end{array}$ \\
\hline 86 & 8720 & $\underline{\underline{90}}$ & TRUSTEE I.I. FUNDS / N/A \\
\hline 88 & 9300 & & SUBSURFACE RIGHTS (OGM'S / N/A \\
\hline 89 & 100 & $\underline{89}$ & $\begin{array}{l}\text { SPECIAL CO-EXEMPTION, \& BACK } \\
\text { ASSESSMENTS / N/A }\end{array}$ \\
\hline 90 & 9900 & 99 & LANDS AVAILABLE FOR TAXES / N/A \\
\hline 91 & 9510 & & RIVERS, CANALS / N/A \\
\hline 92 & 9520 & & LAKES / N/A \\
\hline 93 & 9530 & & SUBMERGED LANDS / N/A \\
\hline 96 & 8000 & & TENATIVE PLAT (NO VALUE) / N/A \\
\hline 98 & 8100 & 95 & MILITARY - FEDERAL / N/A \\
\hline
\end{tabular}

-69 - 


\begin{tabular}{|c|c|c|l|}
\hline Cluc & Sluc & State Ex Code & \multicolumn{1}{c|}{ Description } \\
\hline 98 & 8220 & $\underline{95}$ & $\begin{array}{l}\text { FEDERAL - FOREST, PARKS, RECREATIONAL } \\
\text { AREAS / N/A }\end{array}$ \\
\hline 98 & 8800 & $\underline{95}$ & FEDERAL OWNED - OTHER THEN MILITARY, / N/A \\
\hline 99 & 8700 & $\underline{90}$ & STATE OWNED - OTHER THEN MILITARY, / N/A \\
\hline 99 & 8230 & $\underline{90}$ & $\begin{array}{l}\text { STATE - FOREST, PARKS, RECREATIONAL } \\
\text { AREAS / N/A }\end{array}$ \\
\hline 99 & 8400 & $\underline{30}$ & COLLEGES / N \\
\hline
\end{tabular}

-70 - 
Appendix 3: Assumptions used to interpret information in Appendices 1 and 2 in order to estimate municipal water demand in the MDC.

Assumptions for Municipal Water Use:

All Fractions without units imply GPD per square footage. For both 2001 and 2011 I went through to make sure any home that was vacant or under construction (having 0 square foot and no year built date) was given a water demand of 0 .

2001 Appraiser Shapefile (This file contained no SLUC information). Estimated based on struck through estimations in WASD document (Appendix 1).

$\mathrm{CLUC}=001=\mathrm{SFH}=350 \mathrm{GPD}$

CLUC $=002=$ duplex $=250$ GPD per unit

CLUC $=003=$ apartment $=200 \mathrm{GPD}$ per unit

CLUC $=004=$ some are vacant, those that are not are treated as SFH at 350 GPD

$\mathrm{CLUC}=005-$ cluster homes - treated as SFH

CLUC $=006-$ Mobile Home 300 GPD per unit

CLUC $=007-$ Condos, some vacant. Those with 0 square footage given 0 GPD. Those with square foot were given $200 \mathrm{GPD}$.

CLUC $=009$ - Mixed use, primarily residential. Those that have beds and baths, treat as SFH (350). Those that are just buildings were given 10/100.

CLUC $=010-$ Townhouses - those that have -0 square footage given 0 GPD (vacant), those with square footage given $250 \mathrm{GPD}$ per unit.

CLUC - 011 - This one is tough and very diverse group and no SLUCs to help guide. I looked for those that appeared to be restaurants (fast food) and assumed 50 seat capacities in each. $35 * 50$ GPD

For sit down restaurants I again assumed 50 seats at $50 \mathrm{GPD}$ per seat so $50 * 50$

For gas / auto service I assumed 10/100

All others were treated as office buildings / retail and given 5/100 
CLUC 013 was office buildings and given 10/100

CLUC 014 is Wholesale outlets, produces and is given 50/100

CLUC 015 is entertainment

I treated Redland Country Club like a golf course (see above)

I treated Monkey Jungle like pasture land (see above)

The 2 others were $5 / 100$

CLUC 017 - Only two had buildings and they were given 5/100.

CLUC 019 - Auto Sales, Auto Repair - 10/100

CLUC 022 - Hotels - 100 GPD per unit

CLUC 0026 - Service Stations again 10/100

CLUC 0029 - Mixed Use Commercial 5/100

CLUC 0032 - Assume wet manufacturing at 20/100

CLUC 0034 - Market Food processing Canneries 35/100

CLUC 0036 - Due to lack of specificity and many possible GPD I assumed 10/100 GPD.

CLUC 0037 - Warehouse or storage so 20/1000

CLUC 0041, which is schools, it asks for GPD per student. We don't know that so we assumed 10 GPD per 100 square feet.

CLUC 0043 (retirement homes and hospitals) I assume those buildings with no bathrooms have no water use. For buildings with bathrooms I take 150 GPD per bedroom per the instructions

CLUC 0044 - Houses of Worship Treat houses of worship as 10/100 since old guidance goes by seat and we don't have that info we use new guidance which says 10/100.

CLUC 0047 - County owned housing and other non-school properties. Much is public housing so did 200 GPD per unit for those and those without bedrooms did 10/100.

CLUC 0048 - Schools. Early guidance did by student which we didn't do so I used new guidance of $12 \mathrm{GPD} / 100$. 
CLUC 0054 - Cemeteries like golf courses. (See above)

CLUC 0057 (parsonage) I treat like a SFH. (350 GPD)

CLUC 0062 - Right of way 0 GPD

CLUC 0063 - more right of ways. Those with buildings give 10/100 and those without get 0 .

CLUC 0065 - Parking lots and parking garages get 0 GPD.

CLUC 0066 - Extra Features on vacant lots. NO structures and all 0 GPD.

CLUC 71 thru 81 is Agricultural and will be ignored

CLUC 84 thru 89 will all be ignored since they are state and federal land with the exception of CLUC 099 that is a UF college. I took square footage of building, divided by 5000 and then multiplied 550 GPD like a huge SFH.

2011 Appraiser Shapefile (This file DID contain SLUC information) is Estimates based on non-deleted estimations in WASD document (Appendix 1).

CLUC $001-$ SFH - Less than 3001 square feet $=220 \mathrm{GPD}$

3001 to 5000 square feet $=320 \mathrm{GPD}$

Over $5000=550 \mathrm{GPD}$

CLUC 002 duplex - 180 GPD per unit

CLUC 003 - Apartments 150 GPD per unit

CLUC 004 - Single Family Home Total Value those with no structures are 0 and those with structures are treated like any other SFH.

CLUC 005 - Cluster homes - treated like any other SFH

CLUC 006 - Mobile Homes 180 GPD per unit

No CLUC 007

No CLUC 008

CLUC 009 - Treated like any other SFH (mixed residential) 
CLUC 0010 - Townhouse - 180 GPD per unit (those that are vacant get 0) _

CLUC 011 - Retail Outlet - to determine if it's a market (35 GPD/100),

SLUC $1300=$ department store $10 \mathrm{GPD} / 100$.

SLUC $2100=$ Restaurant with seating $100 \mathrm{GPD} / 100$.

$2200=$ drive thru restaurant $50 / 100$.

$2600=$ gas station 450 GPD. I don't know for 1200 so I left it with 10/100.

1600 is shopping mall.

I leave 2500 as $10 / 100$.

CLUC 013 - Office Building - all get 5/100

CLUC $14=$ wholesale produce. I treated like market 35/100.

CLUC 0015 - Entertainment

CLUC 015 is entertainment

I treated Redland Country Club like a golf course (see above)

I treated Monkey Jungle like pasture land (see above)

The 2 others were $5 / 100$

CLUC 017 - Shopping Centers, etc. were given 10/100

CLUC 0019 - Automotive 10/100

CLUC 0022 - Hotel and motel 100 GPD per room

CLUC 0024 - Migrant camps. Without specific guidance I gave 10/100.

CLUC 0026 - Service Stations were 10/100.

CLUC 0029 - Mixed Commercial 10/100

CLUC 0032 - Assume wet manufacturing at 20/100

CLUC 0034 - Market Food processing Canneries 35/100 
CLUC $36-$ SLUC 4200 is heavy industrial heavy equipment $=$ Industrial Wet 20/100

SLUC 4300 is Sawmills, planning, mills, etc. $=$ Industrial dry 2.5/100

SLUC 4800 is a warehouse $==1 / 100$

SLUCH 4900 is Open storage $=1.5 / 100$

SLUCH 5000 is Agricultural improvement $=10 / 100$

CLUC $37-$ SLUC 4800 9s a warehouse $=1 / 100$

SLUC 4900 SLUCH 4900 is Open storage $=1.5 / 100$

SLUC 5000 SLUCH 5000 is Agricultural improvement $=10 / 100$

SLUC 9900 Acreage not classified as agricultural - Since all of these sites have buildings I will assume 10/100

CLUC 40 SLUC 8200 this is Hammock Restoration. 0 GPD

CLUC 41 SLUC $7200=$ School $=12$ GPD $/ 100$

SLUC $7300=$ Religious School $=12 / 100$

CLUC 42 SLUC $7500=$ Assisted Living Retirement All same as 2001

CLUC $43=1900$ Professional Service Building

SLUC $7400=$ Retirement Home $=$

SLUC $7500=$ Assisted Living, etc.

For all CLUC 43 I do same as 2001. If they have no bathrooms or bedrooms I assume they are like an office building otherwise $150 \mathrm{GPD}$ per bedroom.

CLUC $044=$ Houses of worship 10/100

CLUC $047-$ SLUC $8000=0$ GPD because they are platted sites tentatively

SLUC $8200=$ municipal park (I assume 1 person per 1000 square feet daily $)$ If there is a bathroom I assume toilets. No assumption of showers. So 5/1000

SLUC $8600=$ County-Owned other than Schools. Those that appear to be public housing are given the same as an apartment -150 /unit others are assumed to be 
campgrounds with lodging. I used the $20 \mathrm{GPD}$ per person $(1000$ square feet $=$ a person in my assumption).

CLUC 0048 - Schools. 12/100

CLUC 0051 - These are homeowners' association Common areas. I will assume the same as golf courses since they are heavily landscaped.

CLUC 0052 - Playground - assume landscaped like golf course.

CLUC 0054 - Cemeteries treat as golf courses.

CLUC 0057 - Parsonage treat as a SFH.

CLUC 0062 - Utility right of ways - assume no water.

CLUC 0063 - more right of ways. Those with buildings give 10/100 and without get 0 .

CLUC 0065 - Parking lots and parking garages get 0 GPD.

CLUC 0067 - Extra features on vacant lots. I assumed only those with structures use water and that will be 10/100.

CLUC 0069 - Miscellaneous Uses THE SLUC is 5000 so I took those that appeared to be homes and used the SFH rules. I then took the one other with a structure and did the default 10/100. The rest had no structures so were left at 0 .

CLUC 71 thru 81 is Agricultural and will be ignored.

CLUC 84 thru 89 will all be ignored since they are state and federal land with the exception of CLUC 099 that is a UF college. I took square footage of building, divided by 5000 and then multiplied 550 GPD like a huge SFH. 
Appendix 4: Miami-Dade County Land Use Codes used by Planning Zoning (different from Appendix 2) - used for agricultural water estimation and overall land use change interpretation.

\section{MIAMI-DADE COUNTY DEPARTMENT OF PLANNING AND ZONING LAND USE NUMERIC CLASSIFICATION}

July 2008

Numeric Classification

Miami-Dade Land Use Category

000

RESIDENTIAL

010 Single-Family, Med.-Density (2-5 DU/Gross Acre).

011 Single-Family, High Density (Over 5 DU/Gross Acre, other than Townhouses, Duplexes and Mobile Homes).

012 Townhouses.

013 Single-Family, Low-Density (Under 2 DU/Gross Acre).

020 Two-Family (Duplexes).

030 Multi-Family, Low-Density (Under 25 DU/Gross Acre).

035 Multi-Family, High Density (Over 25 DU/Gross Acre).

$050 \quad$ Migrant Camps.

061 Mobile Home Parks and Permanent Mobile Homes.

100 COMMERCIAL \& SERVICE

101 Shopping Centers (Regional and Community). 
110 Sales and Services (Spot commercial, strip commercial, neighborhood shopping centers/plazas). Excludes office facilities.

112 Marine commercial (includes private commercial [nonrecreational] marinas and repair yards on public or private land).

115 Sports Stadiums, Arenas, and Tracks.

200 Transient-Residential (Hotel-Motel)

$300 \quad$ Industrial 

resulting water body (see 917).

20 Other Industrial Intensive, non-noxious.

339 Other Industrial Extensive, non-noxious.

*340 Other Industrial Intensive, noxious.

*359 Other Industrial Extensive, noxious.

$370 \quad$ Junk Yard.

$400 \quad$ Institutional

411 Public Schools, Including Playgrounds (K-12, Vocational Ed., Day Care and Child Nurseries).

412 Private Schools, Including Playgrounds (K-12, Vocational Ed., Day Care and Child Nurseries).

414 Colleges and Universities, Including Research Centers, Public and Private.

420 Cultural (auditoriums, convention centers, exhibition centers, museums, art galleries, libraries).

$430 \quad$ Hospitals, Nursing Homes and Adult Congregate Living Quarters. $440 \quad$ Houses of Worship and Religious.

450 Governmental/Public Administration (Other than Military or Penal). Military Facilities. 
Penal and Correctional.

470 Social Services, Fraternal, Charitable (Shriners, Elks, Moose, Lions Club).

PARKS AND RECREATIONAL OPEN SPACE (INCLUDING PRESERVES AND CONSERVATION) public tennis courts and pools. Recreational Vehicle Parks/Camps.

* These codes are obsolete and no longer used. The numbers are retained only for historical comparability purposes.

517 Private Recreational Facilities Associated with private Residential Developments, except marinas/yacht basins (See 527).

Private Recreational Camps/Areas not associated with private Residential Developments (Boy Scout/Girl Scout Camps, Private Recreational Camps). Includes private tennis courts and pools that are part of the recreational complex.

Beaches.

Marina complexes (docks, piers, moorings, ramps, boat lifts and hoists, boat maintenance and repair, boat storage, fueling operations) for recreational craft located within Parks and Preserves and other small craft harbor complexes used primarily for recreation, including those associated with private residential 
developments and yacht clubs.

$530 \quad$ Golf courses, Public and Private.

$540 \quad$ Cemeteries.

$550 \quad$ Metropolitan Parks.

$560 \quad$ Everglades National Park.

561 Everglades National Park Expansion (As of 5/1/91).

$562 \quad$ Biscayne National Park.

$570 \quad$ Water Conservation Areas.

580 Other Nature Preserves and Protected Areas (State Mangrove

Preserves, Turkey Point Wilderness Area, Great Cypress Swamp

Preserves, and acquired EEL sites).

600

TRANSPORTATION, COMMUNICATION, AND UTILITIES

610 Airports (other than Military and Small Grass Airports).

611 Small Grass Airports (Includes Crop Dusting Activities).

612 Ocean Ship Terminals and Port Facilities, Bay and River Based.

613 Bus/Truck/Freight Forwarding Terminals.

620 Railroads - Terminals, Trackage, and Yards.

630 Electric Power (Generator and Substation, and Service Yards).

$631 \quad$ Major Transmission Lines.

$632 \quad$ Oil and Gas Storage (Tank Farms).

633 Communications (Radio, TV, Cable, and Phone), excluding 
Antenna Arrays.

$634 \quad$ Antenna Arrays.

635 Water Supply Plants.

$636 \quad$ Sewerage Treatment Plants.

$637 \quad$ Wellfields.

640 Streets and Roads, except Expressways and Private Drives.

$641 \quad$ Paved Expressways and Ramps.

642 Private Drives.

645 Expressway right-of-way and associated open and landscaped areas excluding paved expressways and ramps.

646 Street right-of-way and entrance features both public and private.

650 Parking - Public and Private Garages and Lots.

660 Solid Waste Disposal and Transfer (Includes Dumps, Solid Waste

Land Fills, Resource Recovery Plants and Facilities, Trash Transfer Stations).

$670 \quad$ Road Maintenance and Storage Yards, and Motor Pools.

AGRICULTURE

710

Groves.

720

Row and Field Cropland.

730

Pasture (Grazing, Animal Farming, Dairy Farms and Animal Feed Lots), excluding Horse and Poultry.

Horse Training and Stables. 
Plant Nurseries (Includes Sod Farms and Ornamental Nurseries). Farms). Implements). EEL sites until acquired. Eelsites)

804 Vacant, Non-Protected, Privately-Owned.

$805 \quad$ Vacant, Under Development.

900 INLAND WATER

Rivers and Canals.(Water)

Canal right-of-way.

917 Inland water bodies (Lakes, Rock Pits) associated with extraction, excavation, quarrying and rock-mining activities. 
918 Inland water bodies (Lakes, Watercourses) associated with residential developments.

919 Inland water bodies (Lakes, Ponds, and Watercourses) associated with industrial areas, industrial parks and new industrial development.

920 Other inland water bodies (Lakes, Ponds, Watercourses other than rivers and canals), including road borrow pits.

$930 \quad$ Coastal water bays and ocean

931 Coastal Waters within Everglades National Park.

932 Coastal Water (Bay only) within the Biscayne Bay Urban Aquatic Preserve (Excluding Ocean Waters).

933 Coastal Water (Bay only) within Biscayne Bay National Park (Excluding Ocean Waters.

934 Coastal Water (Ocean only) within Biscayne National Park (Excluding Bay Waters).

935 Remaining Bay Waters (Excluding Ocean).

936 Remaining Ocean Waters (Excluding Bay). 